\title{
molecules
}

ISSN 1420-3049

www.mdpi.com/journal/molecules

Article

\section{Acetylated and Methylated $\beta$-Cyclodextrins as \\ Viable Soluble Supports for the Synthesis of Short 2'-Oligodeoxyribo-nucleotides in Solution}

\author{
Alejandro Gimenez Molina, Vyacheslav Kungurtsev, Pasi Virta and Harri Lönnberg * \\ Department of Chemistry, University of Turku, FIN-20014 Turku, Finland; \\ E-Mails: algimo@utu.fi (A.G.M.); vyakun@utu.fi (V.K.); pamavi@utu.fi (P.V.) \\ * Author to whom correspondence should be addressed; E-Mail: harlon@utu.fi; \\ Tel.: +358-2-333-6770; Fax: +358-2-333-6700.
}

Received: 12 September 2012; in revised form: 12 October 2012 / Accepted: 12 October 2012 /

Published: 16 October 2012

\begin{abstract}
Novel soluble supports for oligonucleotide synthesis 11a-c have been prepared by immobilizing a 5'-O-protected 3'-O-(hex-5-ynoyl)thymidine (6 or 7) to peracetylated or permethylated 6-deoxy-6-azido- $\beta$-cyclodextrins $\mathbf{1 0 a}$ or $\mathbf{1 0 b}$ by $\mathrm{Cu}(\mathrm{I})$-promoted 1,3 -dipolar cycloaddition. The applicability of the supports to oligonucleotide synthesis by the phosphoramidite strategy has been demonstrated by assembling a $3^{\prime}-\mathrm{TTT}-5^{\prime}$ trimer from commercially available $5{ }^{\prime}-O$ - $\left(4,4^{\prime}\right.$-dimethoxytrityl)thymidine 3 '-phosphoramidite. To simplify the coupling cycle, the $5^{\prime}$-O-(4,4'-dimethoxytrityl) protecting group has been replaced with an acetal that upon acidolytic removal yields volatile products. For this purpose, 5'-O-(1-methoxy-1-methylethyl)-protected 3'-(2-cyanoethyl- $N, N$-diisopropylphosphoramidite)s of thymidine (5a), $N^{4}$-benzoyl-2'-deoxycytidine (5b) and $N^{6}$-benzoyl-2'deoxyadenosine $(\mathbf{5 c})$ have been synthesized and utilized in synthesis of a pentameric oligonucleotide $3^{\prime}$-TTCAT-5' on the permethylated cyclodextrin support 11c.
\end{abstract}

Keywords: cyclodextrin; oligonucleotides; phosphoramidites; soluble support; synthesis

\section{Introduction}

The methods currently applied to preparation of oligonucleotides in the laboratory [1,2] as well as in large-scale production [3-5], consist of stepwise addition of nucleoside phosphoramidites to a growing oligomer chain on a solid support. While solid-supported phosphoramidite chemistry 
undoubtedly is the method of choice for small-scale synthesis of oligonucleotides, solution phase synthesis may well challenge it in cases where multikilogram quantities are needed for clinical phase trials of therapeutic oligonucleotides or as starting materials for the construction of nanomaterials. To ensure efficient coupling on a solid support, the expensive phosphoramidite monomers have to be used in large excess and this requirement tends to become even more stringent in scaling up the synthesis [6]. In addition, the support itself is expensive, comprising one third of the overall raw material cost [4]. For these reasons, several strategies for the assembly of oligonucleotides on soluble supports have been suggested. Most of these are based on use of polyethylene glycol (PEG) as a support. PEG allows coupling in $\mathrm{MeCN}$ and may be precipitated by $\mathrm{Et}_{2} \mathrm{O}$. This protocol has been applied to the synthesis of both oligonucleotides and their phosphoromonothioate analogs by the phosphoramidite [7-11], $H$-phosphonate [12], and phosphotriester [13,14] strategies. More recently, the 3'-O-(adamantan-1yl)acetyl group [15] and 3'-O-succinyl-tethered 1-ethyl-3-methylimidazolium tetrafluoroborate salt [16] have been used as soluble supports. The (adamantan-1-yl)acetyl group allows extractive work-up of the growing oligonucleotide chain that, besides conventional benzoyl and isobutyryl protections, additionally bears a pivaloyloxymethyl group at $N 3$ of the thymidine residues [15]. The imidazolium tetrafluoroborate tagged oligomers have, in turn, been separated from small molecular reagents by successive precipitations and extractions. As a complementary approach, solid-supported reagents have been exploited to synthesize oligonucleotides in solution $[17,18]$.

We now report on an alternative approach based on the use of fully protected $\beta$-cyclodextrin as a soluble support and replacement of the conventional 5'-O-(4,4'-dimethoxytrityl) protecting group with an acetal that upon removal gives only volatile products. The cyclodextrin support is sufficiently small to allow efficient coupling and accurate mass spectrometric analysis, but it still is hydrophobic enough so that the separation of the growing oligonucleotide chain from all the reagents can be rapidly realized by flash chromatography with limited solvent consumption. On using methylated cyclodextrin, the support may be removed by extraction after the ammonolytic release and deprotection of the oligonucleotide.

\section{Results and Discussion}

\subsection{Preparation of Nucleosidic Building Blocks}

Scheme 1 outlines the preparation of 5'-O-(1-methoxy-1-methylethyl) protected 2'-deoxyribonucleoside 3 '-phosphoramidites used as building blocks in the oligonucleotide chain assembly. The 3'-O-(tert-butyldimethylsilyl)ated nucleosides $\mathbf{2 a - c}$, used as the starting materials for the introduction of the $5^{\prime}$-acetal protection, were obtained in two different manners. Thymidine was first converted to 3',5'-di-O-(tert-butyldimethylsilyl)thymidine (1a) and the 5'-O-silyl group was then removed by acidcatalyzed hydrolysis to obtain 2a. Commercially available $N$-benzoylated 5'-O-(4,4'-dimethoxytrityl)2'-deoxy-cytidine and -adenosine were, in turn, converted to their 3'-O-(tert-butyldimethylsilyl) counterparts by silylation of $\mathbf{1 b}, \mathbf{c}$ and subsequent acid-catalyzed detritylation to $\mathbf{2 a , c}$. The exposed 5 -hydroxy function was then subjected to acid-catalyzed acetalization with 2-methoxypropene to obtain 5'-protected nucleosides $\mathbf{3 a - c}$, which were desilylated to afford $\mathbf{4 a - c}$. 
Scheme 1. Preparation of nucleosidic building blocks.

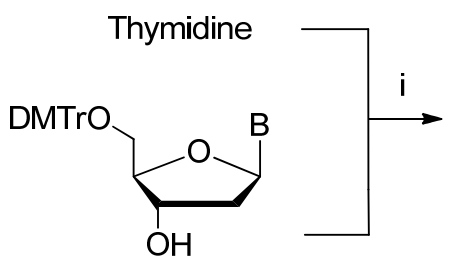

B: $N^{4}$-Bz-Cyt

$N^{6}$-Bz-Ade

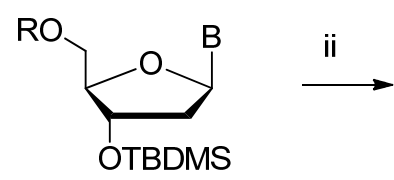

1a: $B=$ Thy, $R=$ TBDMS $(87 \%)$

b: $\mathrm{B}=N^{4}-\mathrm{Bz}-\mathrm{Cyt}, \mathrm{R}=\mathrm{DMTr}(92 \%)$

c: $B=N^{6}-B z-$ Ade, $R=\operatorname{DMTr}(89 \%)$

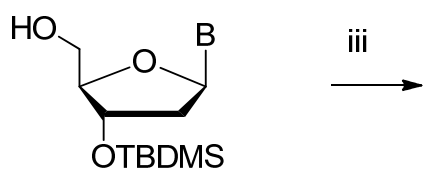

2a: $\mathrm{B}=$ Thy $(81 \%)$

b: $\mathrm{B}=N^{4}-\mathrm{Bz}-\mathrm{Cyt}(90 \%)$

c: $\mathrm{B}=N^{6}$-Bz-Ade $(84 \%)$
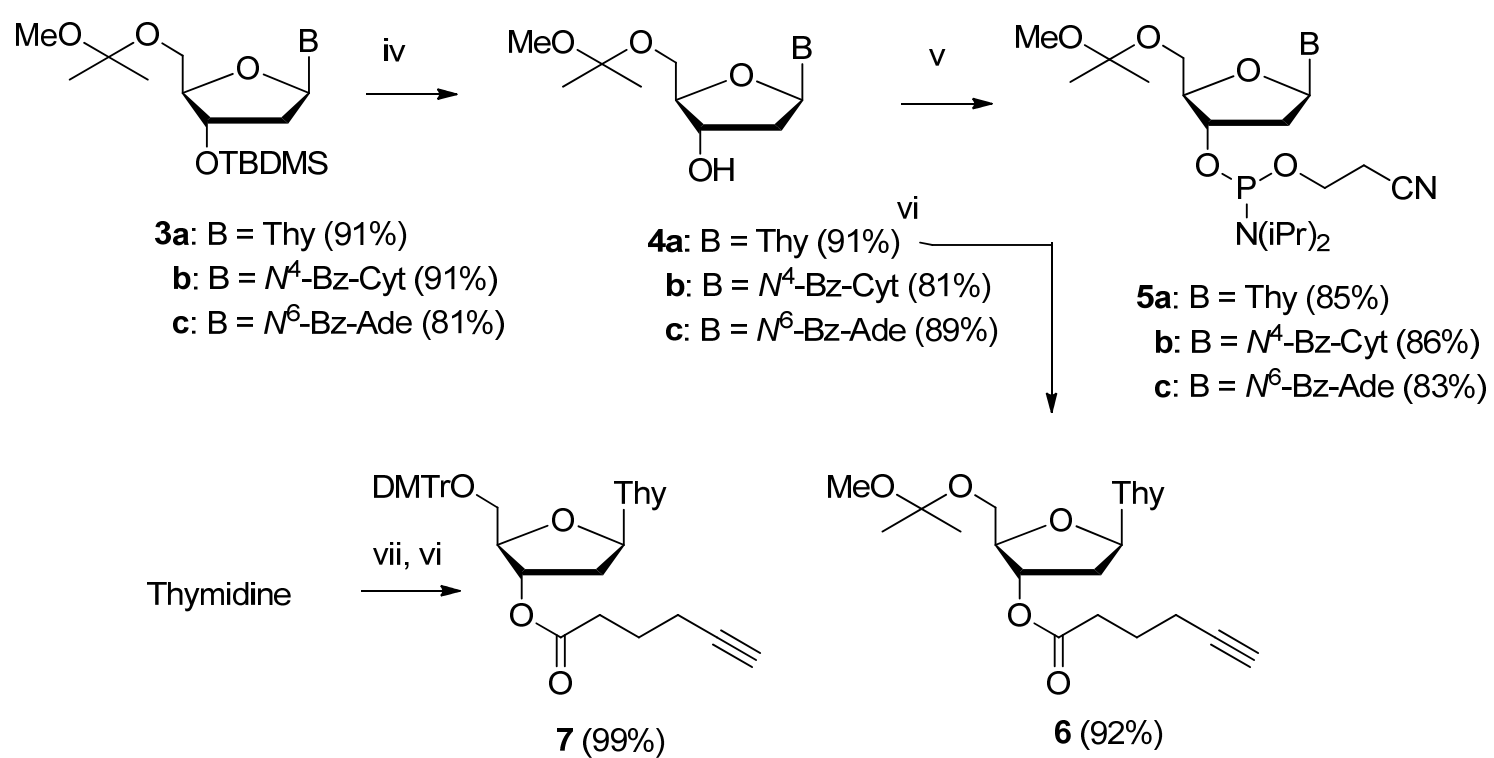

(i) TBDMSCl, Im, DMF; (ii) TFA, aq. THF for 1a; 3\% DCA, MeOH, DCM for $\mathbf{1 b}, \mathbf{c}$; (iii) 2-methoxypropene, TsOH, dioxane; (iv) TBAF, THF; (v) 1-chloro-1-(2-cyanoethoxy)- $N, N$ diisopropylphosphinamine, $\mathrm{Et}_{3} \mathrm{~N}, \mathrm{DCM}$; (vi) 1. 5-hexynoic acid, DCC, dioxane, 2. 4a, Py; (vii) DMTrCl, Py.

The phosphoramidite building blocks 5a-c were finally obtained by phosphitylating the exposed 3'-hydroxy function with 1-chloro-1-(2-cyanoethoxy)- $N, N$-diisopropylphosphinamine. To enable immobilization to an azido-functionalized support, the acetal protected thymidine 4a was esterified with 5-hexynoic acid to obtain 6. For comparative purposes, a similar derivative 7 was prepared from 5'-O-(4,4'-dimethoxytrityl)thymidine.

\subsection{Preparation of Cyclodextrin-Derived Supports}

The soluble supports utilized in the oligonucleotide chain assembly were prepared by immobilizing 5'-protected 3'-O-(hex-5-ynoyl)thymidines 6 or 7 on an azido-functionalized peracetylated or permethylated $\beta$-cyclodextrin (Scheme 2). For this purpose, $\beta$-cyclodextrin was first monotosylated to 8 [19] and the tosyl group was displaced with azide ion. The azido-functionalized cyclodextrin 9 obtained was then acetylated with excess of acetic anhydride in pyridine, yielding 10a, or methylated to $\mathbf{1 0 b}$ with an equimolar mixture of sodium hydroxide and methyl iodide in DMSO [20,21]. The alkyne-functionalized thymidines, either 6 or 7, were finally conjugated to the azido group by $\mathrm{Cu}(\mathrm{I})$ promoted 1,3-dipolar cycloaddition [22,23]. The identity and homogeneity of the products before and 
after conjugation were checked by ESI-MS and HPLC. The data referring to acetylated and methylated supports 11a and 11c after removal of the 5'-O-protecting group from thymidine is given in Figure 1.

Scheme 2. Preparation of cyclodextrin supports.
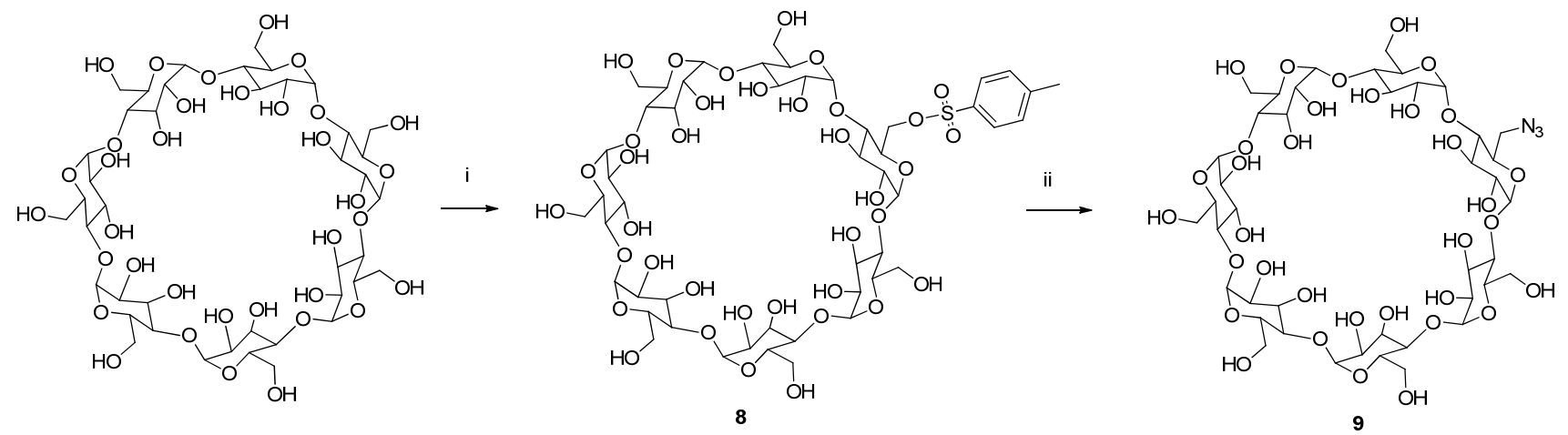

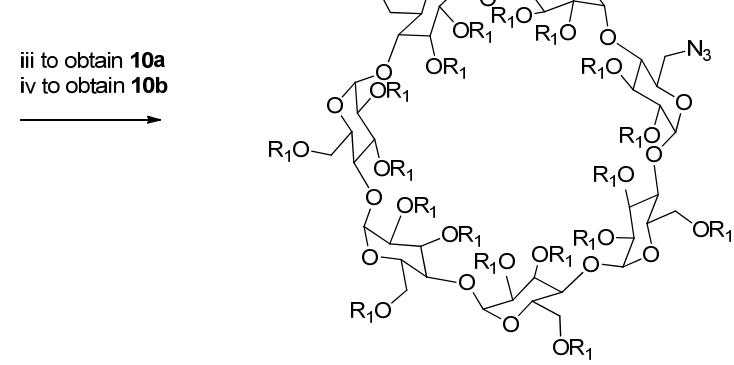

$\begin{aligned} \text { 10a: } R_{1} & =A c \\ \text { b: } R_{1} & =M e\end{aligned}$

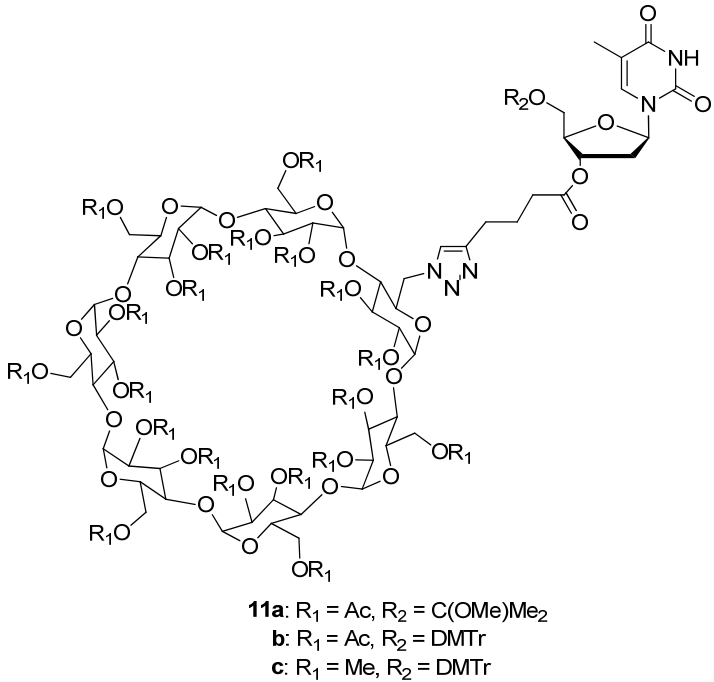

(i) $\mathrm{TsCl}, \mathrm{Py}$; (ii) $\mathrm{NaN}_{3}, \mathrm{KI}, \mathrm{DMF}$; (iii) $\mathrm{Ac}_{2} \mathrm{O}$, Py; (iv) $\mathrm{NaOH}, \mathrm{MeI}, \mathrm{DMSO}$; (v) $\mathrm{CuSO}_{4}$, sodium ascorbate and $\mathbf{6}$ to obtain 11a, and 7 to obtain 11b.

\subsection{Assembly of Oligonucleotides from 5'-O-(4,4'-Dimethoxytrityl) Building Blocks}

The efficiency of phosphoramidite coupling on a cyclodextrin support was first tested by using commercially available 5'-(4,4'-dimethoxytrityl)thymidine 3'-(2-cyanoethyl- $N, N$-diisopropylphosphoramidite) building blocks for coupling on the peracetylated support 11b. Accordingly, the DMTr group of $11 \mathrm{C}$ was removed by $1 \mathrm{~h}$ treatment with $3 \%$ dichloroacetic acid in DCM, a $\mathrm{DCM} / \mathrm{HCO}_{3}{ }^{-}$-workup was carried out and the organic phase was evaporated to dryness. Phosphoramidite coupling was then carried out in $\mathrm{MeCN}$ ( $1 \mathrm{~h}$ at r.t.), using 1.5 equiv. of the phosphoramidite building block and tetrazole compared to support-bound thymidine. The coupling cycle was completed by conventional $\mathrm{I}_{2}$ oxidation in aqueous lutidine/THF and subsequent $\mathrm{DCM} / \mathrm{HSO}_{3}{ }^{-}$-workup. After the second similar coupling step, the overall yield of the support bound fully protected thymidine trimer determined by UV-spectroscopy was $85 \%$, corresponding to $92 \%$ coupling yield. The homogeneity of the product was verified by RP-HPLC after ammonolytic release from the support (HPLC trace A in Figure 2). 
Figure 1. Negative ion ESI-MS $\left([\mathrm{M}-\mathrm{H}]^{-}\right)$and HPLC traces for the thymidine derivatized cyclodextrin supports 11a (A) and 11c (B) after removal of the 5'-O-protecting group from thymidine. Chromatographic conditions: a Thermo ODS Hypersil C18 $(250 \times 4.6 \mathrm{~mm}$, $5 \mu \mathrm{m}$ ) column eluted with a mixture of $\mathrm{MeCN}$ and aq. triethylammonium acetate $\left(0.1 \mathrm{~mol} \cdot \mathrm{L}^{-1}\right)$ at flow rate $1 \mathrm{~mL} \cdot \mathrm{min}^{-1}$. For support $\mathrm{A}$, a linear gradient elution from $\mathrm{MeCN}$ $50 \%$ at $t=0$ to $\mathrm{MeCN} 100 \%$ at $t=20 \mathrm{~min}$. For support $\mathrm{B}$, a linear gradient from $\mathrm{MeCN} 0 \%$ at $t=0$ to $\mathrm{MeCN} 60 \%$ at $t=25 \mathrm{~min}$, and then to $\mathrm{MeCN} 100 \%$ at $t=30 \mathrm{~min}$.
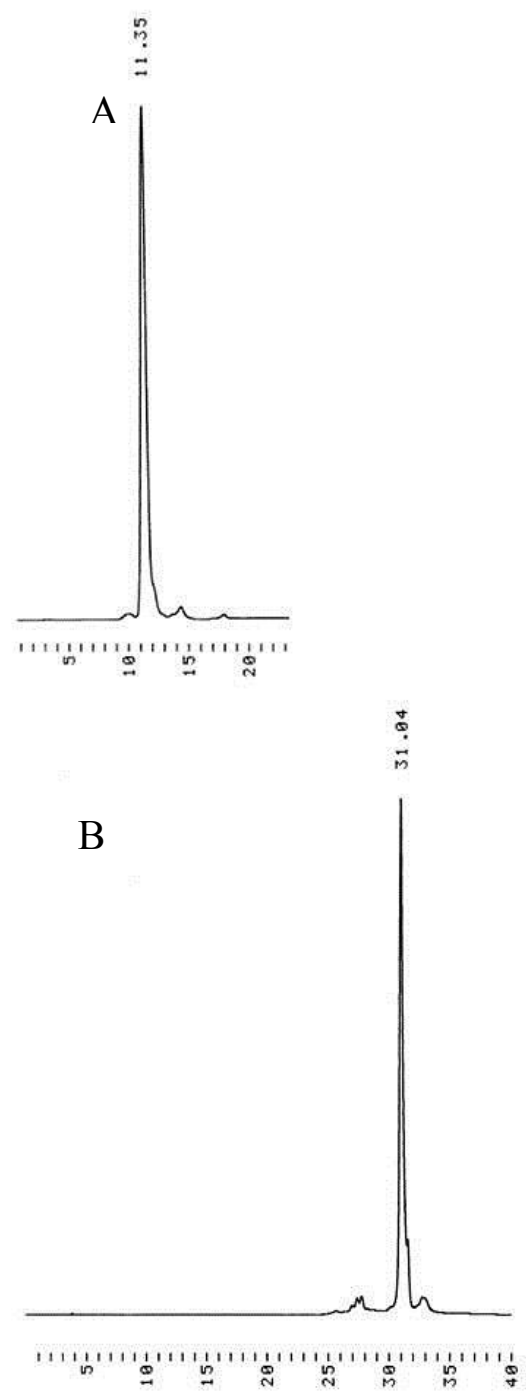
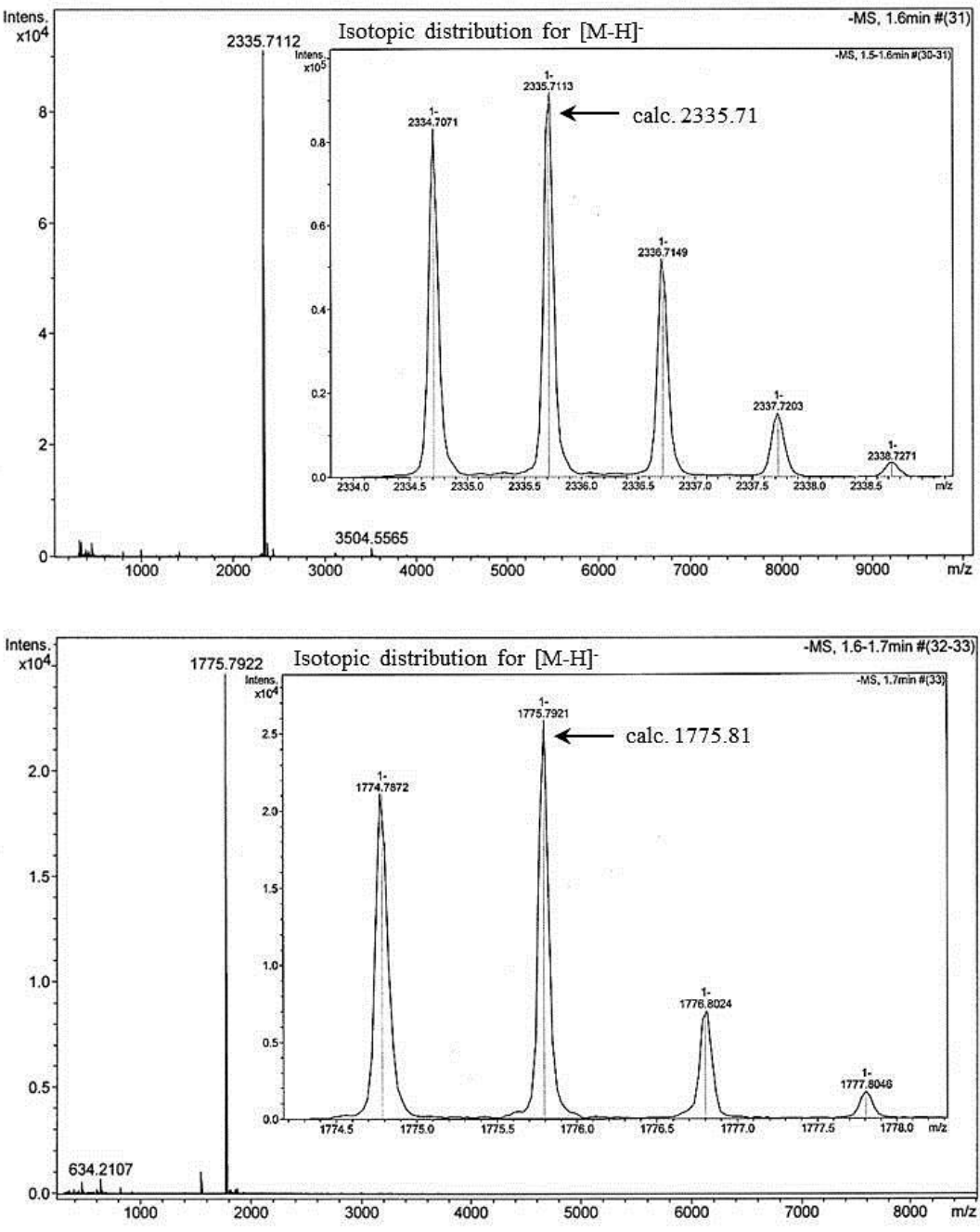

\subsection{Assembly of Oligonucleotides from 5'-O-(1-Methoxy-1-methylethyl) Building Blocks}

Although the initial studies described above clearly show that high coupling yield may be achieved on a cyclodextrin support even when using only 50\% excess of the monomeric building block, the protocol utilized do not allow synthesis of longer sequences, owing to accumulation of 4,4'-dimethoxytrityl alcohol upon repeated couplings. Removal of this compound from the reaction mixture prior to next coupling is difficult, since the support bearing the protected oligonucleotide and dimethoxytrityl alcohol both are rather hydrophobic and, hence, removal by extraction or flash chromatography is not straightforward. For this reason, it appeared attractive to replace the conventional dimethoxytrityl protection with an acid-labile acetal protection, viz. with 1-methoxy-1-methylethyl 
group, which upon acid-catalyzed transesterification with $\mathrm{MeOH}$ was released as volatile dimethyl acetal of acetone. As seen from Figure 3, removal of the 5'-protecting group by $\mathrm{HCl}$ in a 2:1 $(v / v)$ mixture of 1,4-dioxane and $\mathrm{MeOH}$ was sufficiently faster than depurination of N6-benzoyl-2'-deoxyadenosine to allow virtually quantitative removal of the acetal protection without appreciable depurination.

Figure 2. HPLC traces of the crude product of $3^{\prime}-\mathrm{TTT}-5^{\prime}$ prepared from $5^{\prime}-O-\left(4,4^{\prime}-\right.$ dimethoxytrityl)thymidine phosphoramidite on acetylated cyclodextrin support 11b (traces $\mathbf{A}$ ), from 5'-O-(1-methoxy-1-methylethyl)thymidine phosphoramidite (5a) on acetylated support 11a (traces B), and from the same building block (5a) on methylated support 11c (traces C). Chromatographic conditions: a Thermo ODS Hypersil C18 $(250 \times 4.6 \mathrm{~mm}$, $5 \mu \mathrm{m})$ column eluted with a mixture of $\mathrm{MeCN}$ and aq. triethylammonium acetate $\left(0.1 \mathrm{~mol} \cdot \mathrm{L}^{-1}\right)$ at flow rate $1 \mathrm{~mL} \cdot \mathrm{min}^{-1}$. A linear gradient from $\mathrm{MeCN} 0 \%$ at $t=0$ to $\mathrm{MeCN}$ $50 \%$ at $t=20 \mathrm{~min}$, and then to $\mathrm{MeCN} 100 \%$ at $t=25 \mathrm{~min}$.

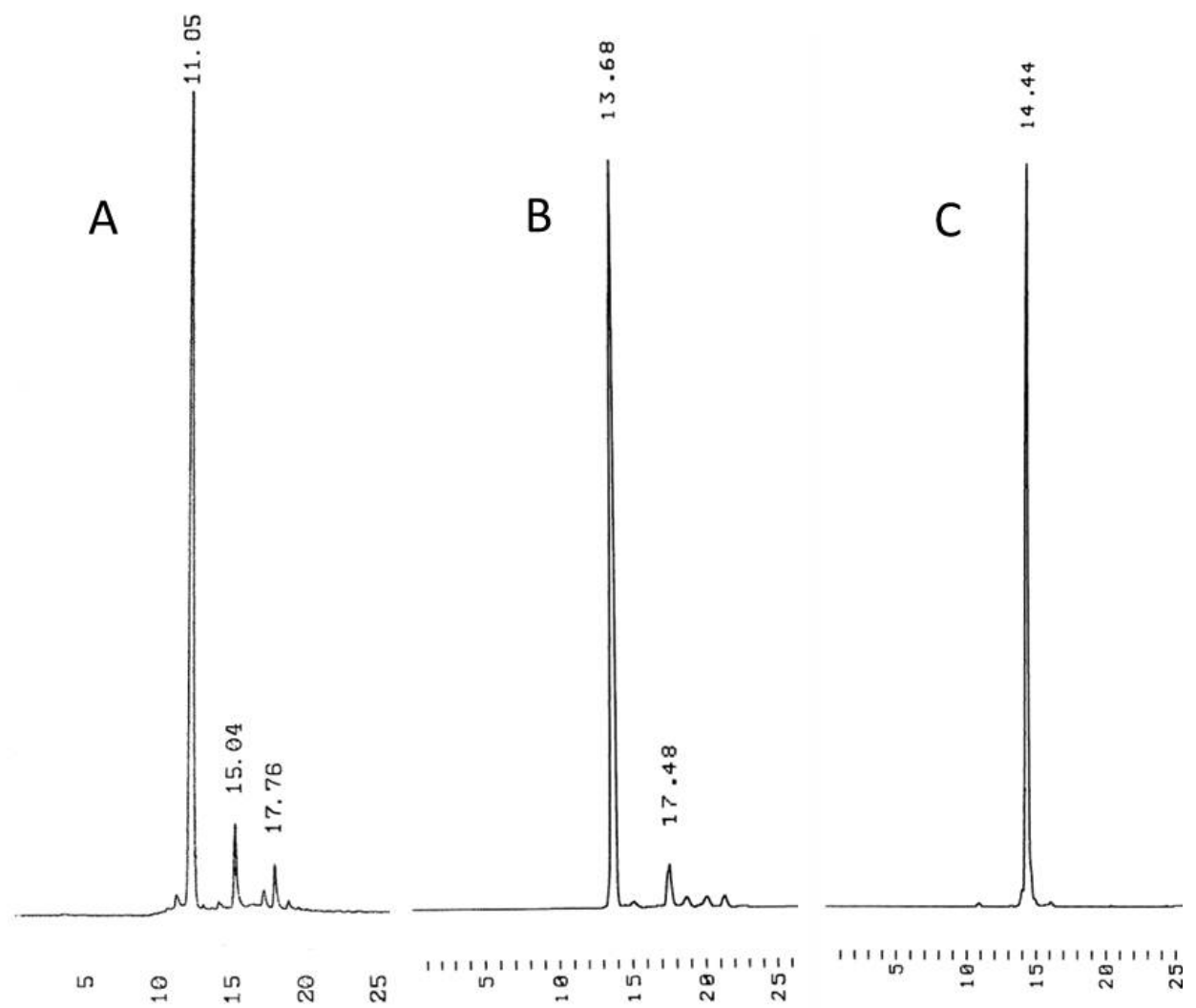

The synthesis of $3^{\prime}-\mathrm{TTT}-5^{\prime}$ was then repeated using 11a as a support and 5a as a building block. The 5'-O-(1-methoxy-1-methylethyl) protection was first removed by $30 \mathrm{~min}$ treatment with $\mathrm{HCl}$ $\left(0.1 \mathrm{~mol} \cdot \mathrm{L}^{-1}\right)$ in a 2:1 mixture of dioxane and $\mathrm{MeOH}$. The volatiles were removed under reduced pressure and traces of $\mathrm{MeOH}$ were removed by coevaporation with dry pyridine. It is worth noting that traces of pyridine in the product do not harm the subsequent coupling. ESI-MS analysis of the residue verified quantitative removal of the protecting group; only the $[\mathrm{M}-\mathrm{H}]^{-}$signal at $\mathrm{m} / \mathrm{z} 2335.71$ referring to the deprotected product appeared, no sign of the $[\mathrm{M}-\mathrm{H}]^{-}$signal of 2407.75 corresponding to the protected support was observed. 
Figure 3. HPLC traces of $N^{6}$-benzoyl-5'-O-(1-methoxy-1-methylethyl)-2'-deoxyadenosine $\left(2 \mathrm{mmol} \cdot \mathrm{L}^{-1}\right)$ treated for $10 \mathrm{~min}$ with $\mathrm{HCl}\left(10^{-4} \mathrm{~mol} \cdot \mathrm{L}^{-1}\right)$ in a $2: 1(\mathrm{v} / \mathrm{v})$ mixture of 1,4-dioxane and $\mathrm{MeOH}$ at $25{ }^{\circ} \mathrm{C}$. Notation: Starting material at 21.6-22.0 min, $N^{6}$-benzoyl-2'-deoxyadenosine at 17.8-18.2 min and $N^{6}$-benzoyladenine at 18.8-19.6 min. Chromatographic conditions: a Thermo ODS Hypersil C18 $(250 \times 4.6 \mathrm{~mm}, 5 \mu \mathrm{m})$ column eluted with a mixture of $\mathrm{MeCN}$ and aq. triethylammonium acetate $\left(0.1 \mathrm{~mol} \cdot \mathrm{L}^{-1}\right)$ at flow rate $1 \mathrm{~mL} \cdot \mathrm{min}^{-1}$. A linear gradient from $\mathrm{MeCN} 0 \%$ at $t=0$ to $\mathrm{MeCN} 60 \%$ at $t=25 \mathrm{~min}$, and then to $\mathrm{MeCN} 100 \%$ at $t=30 \mathrm{~min}$.

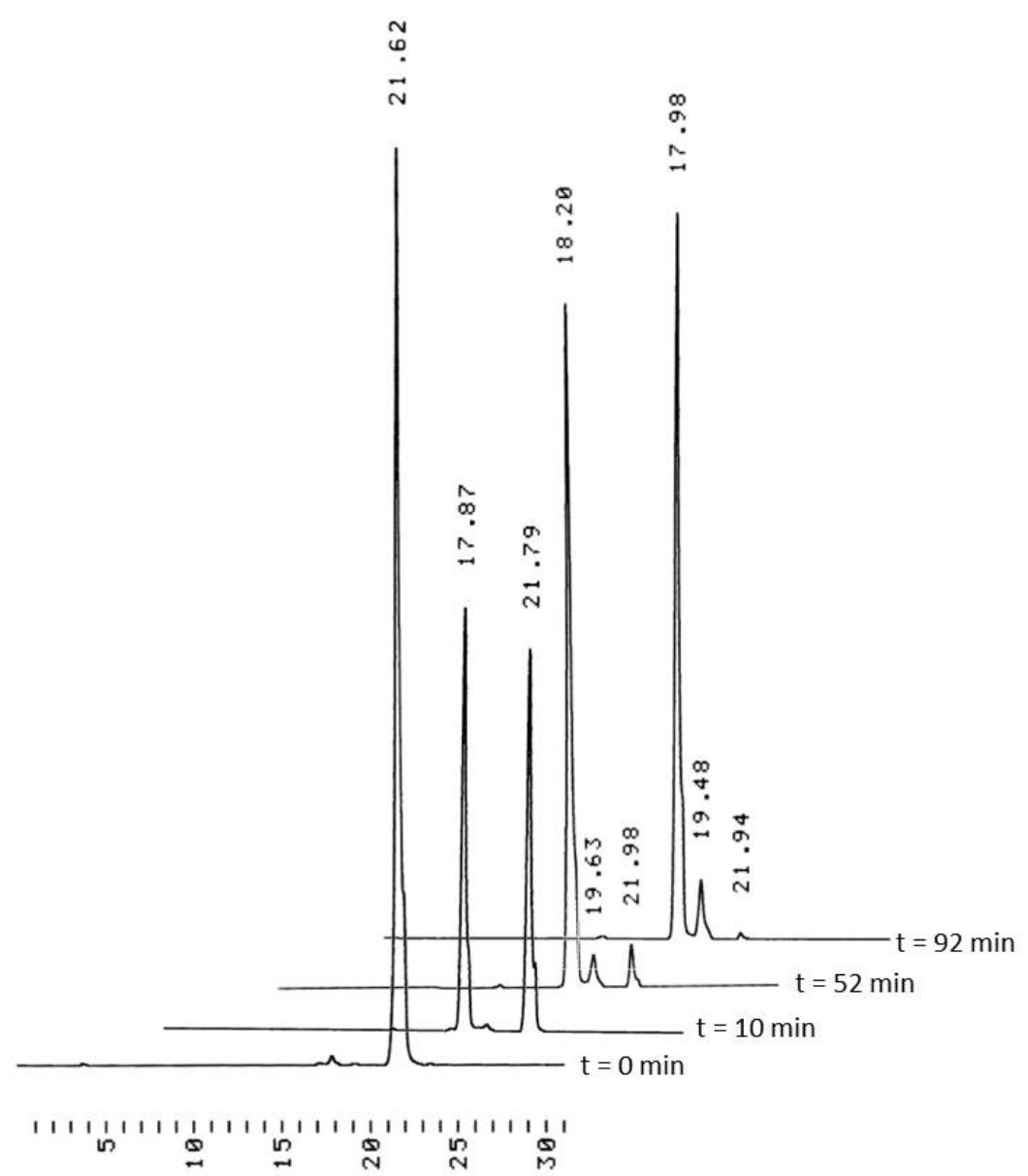

Deprotected 11a was then subjected to coupling with 1.5 equiv. of 5a in MeCN under nitrogen, using 4,5-dicyanoimidazole as an activator ( $6 \mathrm{~h}$ at r.t.), and the phosphite triester obtained was oxidized by addition of $\mathrm{I}_{2}$ in aq. lutidine/THF (30 min at r.t.). Upon DCM/ $\mathrm{HSO}_{3}{ }^{-}$-workup, lutidine was partly transferred to the organic phase and, hence, the soluble-supported product obtained by evaporation of DCM still contained traces of lutidine. The residue was dissolved in a 2:1 mixture of dioxane and $\mathrm{MeOH}$ and the $\mathrm{pH}$ of the solution was adjusted between 4 and 5 to remove the $5^{\prime}$-acetal protection and the reaction was allowed to proceed for $1 \mathrm{~h}$. To remove the traces of reagents and the products formed from the unreacted building block upon oxidation, the support was purified by flash chromatography on a short silica gel column before the next coupling. The overall yield after two couplings, determined by UV-spectroscopy, was $87 \%$, corresponding to $93 \%$ coupling yield. The trimer released by ammonolysis was homogeneous by RP-HPLC (trace B in Figure 2). 
The shortcoming of acetylated cyclodextrin as a support is that it does not withstand ammonolysis, but is converted to hydrophilic products that render the isolation of the oligonucleotide product difficult, necessitating reversed phase HPLC purification. To avoid this, the acetylated cyclodextrin support 10a was replaced with the methylated one, 11c, and the synthesis of 3'-TTT-5' was repeated. The yield of the synthesis and the homogeneity of the product were similar to those observed for the acetylated support, but now the support could be removed by extraction after the ammonolysis. The HPLC traces of the crude product mixture are shown in Figure 2C.

Finally a hetero-sequence containing 2'-deoxyadenosine and 2'-deoxycytidine in addition to thymidine was assembled on support 11c. Accordingly, the deprotected support bearing the first nuclesoide was dissolved in $\mathrm{MeCN}$ and 1.5 equiv. of the monomeric building block in MeCN was added dropwise, followed by 1.5 equiv. of 4,5-dicyanoimidazole in $\mathrm{MeCN}$. The final concentration of 5a in the reaction mixture was $40 \mathrm{mmol} \mathrm{L}{ }^{-1}$. The reaction was allowed to proceed for $20 \mathrm{~h}$ at r.t. after which oxidation with iodine in a 6:1 ( v/v) mixture of aq. THF and 2,6-lutidine was carried out (45 min). After aq. $\mathrm{NaHSO}_{3} / \mathrm{DCM}$ work-up, the organic phase was dried over $\mathrm{Na}_{2} \mathrm{SO}_{4}$, filtered and evaporated to dryness under reduced pressure. The residue was dissolved in a 2:1 $(v / v)$ mixture of dioxane and $\mathrm{MeOH}$ and $\mathrm{HCl}$ in dioxane $\left(0.1 \mathrm{~mol} \cdot \mathrm{L}^{-1}\right)$ was added to adjust the $\mathrm{pH}$ to 4 . After $2 \mathrm{~h}$ agitation, the mixture was evaporated to dryness and coevaporated with pyridine and $\mathrm{MeCN}$. A rapid column chromatography on a short column was applied to remove the excess of the unreacted building block. Fractions containing the desired product were mixed, evaporated by under reduced pressure and dried under high vacuum. The identity of the support bound dimer was verified by ESI-MS. The same coupling cycle was then repeated by using $\mathbf{5 b}, \mathbf{5 c}$ and again $\mathbf{5 a}$ as building blocks. However, the coupling mixture contained about 20\% DCM to ensure complete dissolution of the cyclodextrin-bound starting material. Finally, conventional ammonolysis was carried out to release and deprotect the pentameric oligonucleotide and the support was removed by equilibration between water and DCM. The gravimetrically determined overall yield of the pentamer was $52 \%$, corresponding to $85 \%$ average coupling yield. Figure 4 shows the identity and homogeneity of the pentamer.

Figure 4. HPLC traces and ESI-MS of the crude product of $3^{\prime}$-TTCAT-5'. For the chromatographic conditions, see the legend of Figure 2.
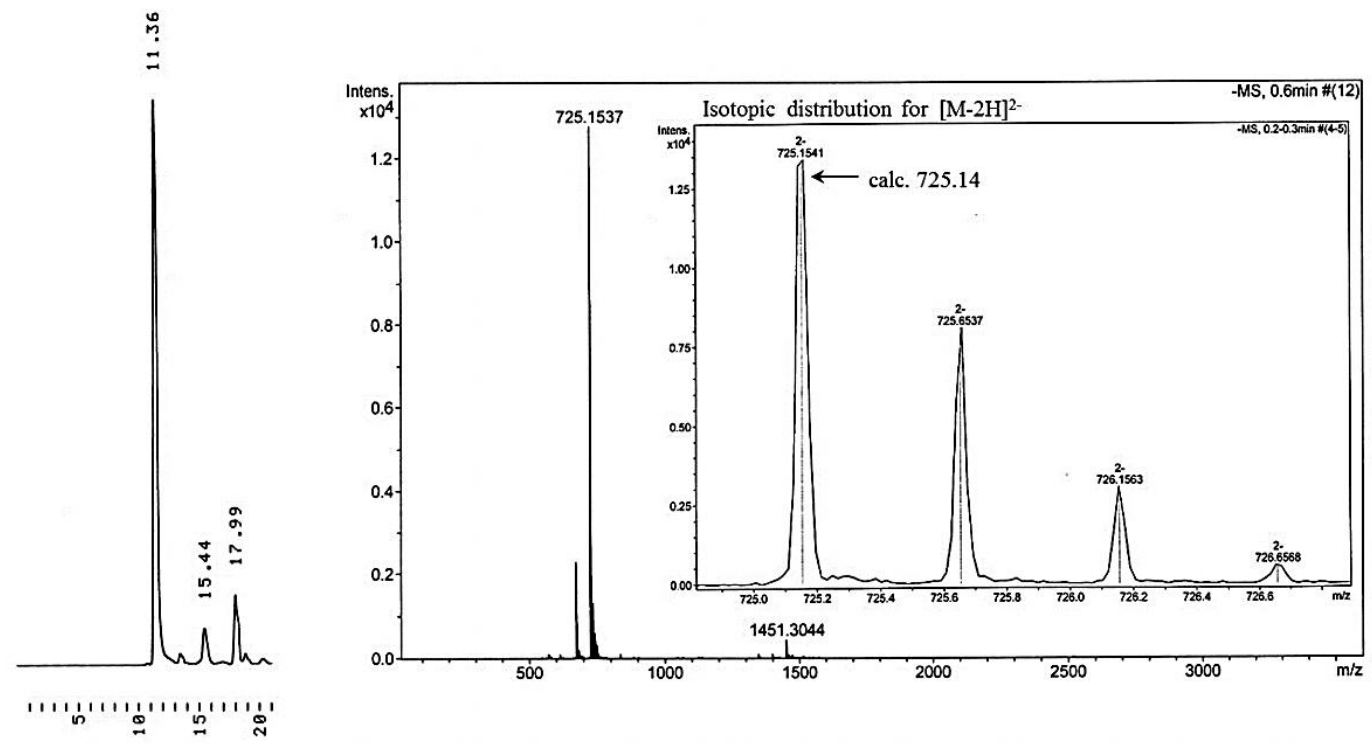


\section{Experimental}

\subsection{General}

Reactions were monitored by TLC (Merck, Silica gel $60 \mathrm{~F}_{254}$ ), using short wavelength UV, $\mathrm{KMnO}_{4}$ staining or burning with $10 \%$ aq. $\mathrm{H}_{2} \mathrm{SO}_{4}$ for detection. $1 \mathrm{D}$ and $2 \mathrm{D}$ NMR spectra were recorded on a Bruker Avence $500 \mathrm{MHz}$ or $400 \mathrm{MHz}$ at $25^{\circ} \mathrm{C}$. The chemical shifts are given in ppm. Mass spectra were recorded on a Bruker Daltonics MicrOTOF-Q spectrometer using ESI ionization. RP HPLC was performed on a Thermo ODS Hypersil C18 $(250 \times 4.6 \mathrm{~mm}, 5 \mu \mathrm{m})$ column using UV detection at $260 \mathrm{~nm}$.

\subsection{Materials}

3',5'-Di-O-(tert-butyldimetylsilyl)thymidine (1a) was synthesized as described previously [24]. Thymidine (41.3 mmol; $10.02 \mathrm{~g}$ ) was dissolved in DMF (35 mL). Imidazole (264 mmol, $18.0 \mathrm{~g})$ in DMF (65 mL) and tert-butyldimethylsilyl chloride (131 mmol; $19.87 \mathrm{~g})$ in DMF $(25 \mathrm{~mL})$ were added. The mixture was stirred at r.t. for $70 \mathrm{~h}$ and then equilibrated between water $(50 \mathrm{~mL})$ and diethyl ether $(50 \mathrm{~mL})$. The organic phase was washed twice with water, dried over $\mathrm{Na}_{2} \mathrm{SO}_{4}$ and concentrated to white solid $(87 \%, 16.93 \mathrm{~g})$. The crude product was subjected to desilylation (cf. preparation of compd. 2a) without further purification. The ${ }^{1} \mathrm{H}$ - and ${ }^{13} \mathrm{C}-\mathrm{NMR}$ spectra were identical to those reported in literature [25,26]. Positive ion ESI-MS: $m / z$ obsd. $471.28[\mathrm{M}+\mathrm{H}]^{+}, 493.27[\mathrm{M}+\mathrm{Na}]^{+}, 509.24[\mathrm{M}+\mathrm{K}]^{+}$; calcd. $471.27[\mathrm{M}+\mathrm{H}]^{+}, 493.25[\mathrm{M}+\mathrm{Na}]^{+}, 509.23[\mathrm{M}+\mathrm{K}]^{+}$.

$N^{4}$-Benzoyl-5'-O-(4,4'-dimethoxytrityl)-3'-O-(tert-butyldimethylsilyl)-2'-deoxycytidine (1b). Commercially available $N^{6}$-benzoyl-5'-O-(4,4'-dimethoxytrityl)-2'-deoxycytidine $(1.42 \mathrm{mmol}, 0.90 \mathrm{~g})$ was dissolved in DMF $(5 \mathrm{~mL})$. tert-Butyldimethylsilyl chloride $(0.33 \mathrm{~g}, 2.35 \mathrm{mmol}, 1.5$ equiv.) and imidazole $(0.29 \mathrm{~g}$, $4.70 \mathrm{mmol}, 3$ equiv.) were added and the reaction was allowed to proceed for $15 \mathrm{~h}$ at $\mathrm{r}$.t. The mixture was equilibrated between water and EtOAc. The organic phase was dried on $\mathrm{Na}_{2} \mathrm{SO}_{4}$ and concentrated to dryness, giving $\mathbf{1 b}$ in $92 \%$ yield $(1.31 \mathrm{mmol}, 0.98 \mathrm{~g})$. The ${ }^{1} \mathrm{H}$ - and ${ }^{13} \mathrm{C}-\mathrm{NMR}$ spectra were identical with those reported in literature [27]. Negative ion ESI-MS: $m / z$ obsd. $746.32[\mathrm{M}-\mathrm{H}]^{-}$; calcd. 746.33 $[\mathrm{M}-\mathrm{H}]^{-}$.

$N^{6}$-Benzoyl-5'-O-(4,4'-dimethoxytrityl)-3'-O-(tert-butyldimethylsilyl)-2'-deoxyadenosine $\quad(\mathbf{1 c}) \quad$ was obtained in $89 \%$ yield (1.55 mmol, $1.20 \mathrm{~g})$ from commercial $N^{6}$-benzoyl-5'-O-(4,4'-dimethoxytrityl)$2^{\prime}$-deoxyadenosine as described above for compd. 1b. ${ }^{1} \mathrm{H}-\mathrm{NMR}\left(500 \mathrm{MHz}, \mathrm{CDCl}_{3}\right): \delta=0.00(\mathrm{~s}, 6 \mathrm{H}$, $\mathrm{SiMe}_{2}$ ), 0.84 (s, 9H, SiCMe $), 2.24-2.29$ (m, 1H, H2'), 2.35-2.44 (m, 1H, H2'), 3.18 (d, J=11.2 Hz, 1H, H5'), 3.29 (d, $\left.J=11.2 \mathrm{~Hz}, 1 \mathrm{H}, \mathrm{H} 5^{\prime}\right), 3.68$ (s, 6H, OMe), 3.96-4.00 (m, 1H, H4'), 4.71-4.77 (m, $\left.1 \mathrm{H}, \mathrm{H3}^{\prime}\right), 6.38$ (m, 1H, H1'), 6.74 (d, $\left.J=9.7 \mathrm{~Hz}, 4 \mathrm{H}, \mathrm{DMTr}\right), 7.20-7.40$ (m, 9H, DMTr), 7.60-8.00 (m, $5 \mathrm{H}, \mathrm{Bz}), 8.24(\mathrm{~s}, 1 \mathrm{H}, \mathrm{H} 2), 8.56(\mathrm{~s}, 1 \mathrm{H}, \mathrm{H} 8), 9.52(\mathrm{~s}, 1 \mathrm{H}, \mathrm{NH}) .{ }^{13} \mathrm{C}-\mathrm{NMR}\left(126 \mathrm{MHz}, \mathrm{CDCl}_{3}\right) \delta=-4.6$ (SiMe), -3.9 (SiMe), 17.3 ( $\left.\mathrm{SiCMe}_{3}\right), 24.8$ ( $\left.\mathrm{SiCMe}_{3}\right), 38.8$ (C2'), $54.6(\mathrm{OMe}), 62.9$ (C5'), 71.7 (C3'), 84.1 (C4'), 85.7 (DMTr), 86.0 (C1'), 112.7 (DMTr), 116.9 (DMTr), 126.4 (C5), 127.4 (DMTr), 127.6 (Bz), 127.8 (DMTr), 128.3 (Bz), 129.6 (DMTr), 132.1 (Bz), 133.6 (Bz), 135.3 (DMTr), 142.4 (C8), 144.7 (DMTr), 149.5 (C4), 151.4 (C2), 151.5 (C6), 158.3 (DMTr), 164. 9 (C=O). Negative ion ESI-MS: $m / z$ obsd. $770.3509[\mathrm{M}-\mathrm{H}]^{-}$; calcd. $770.3374[\mathrm{M}-\mathrm{H}]^{-}$. 
3'-O-(tert-Butyldimethylsilyl)thymidine (2a). A 1:1:4 ( $v / v / v)$ mixture of TFA, water and THF (30 mL) was added dropwise on an ice-bath to compd. 1a dissolved in a minimal volume of THF. After $1.5 \mathrm{~h}$, another portion $(30 \mathrm{~mL})$ of the same mixture was added. The progress of desilylation was monitored by TLC and the reaction was quenched after $5.5 \mathrm{~h}$ by equilibration between diethyl ether and aq. $\mathrm{NaHCO}_{3}$ (sat). The organic phase was washed with aq. $\mathrm{NaHCO}_{3}$, dried over $\mathrm{Na}_{2} \mathrm{SO}_{4}$ and concentrated to white solid foam $(81 \%, 10.38 \mathrm{~g})$. The ${ }^{1} \mathrm{H}-\mathrm{NMR}$ spectrum $\left(500 \mathrm{MHz}, \mathrm{CDCl}_{3}\right)$ was identical to that reported previously [28]. ${ }^{13} \mathrm{C}-\mathrm{NMR}\left(126 \mathrm{MHz}, \mathrm{CDCl}_{3}\right): \delta=-4.9(\mathrm{SiMe}),-4.8(\mathrm{SiMe}), 12.4(\mathrm{C} 5-\mathrm{Me})$, $17.9\left(\mathrm{SiCMe}_{3}\right), 25.7\left(\mathrm{SiC}\left(\mathrm{CH}_{3}\right)_{3}\right), 40.7\left(\mathrm{C}^{\prime}\right), 61.8\left(\mathrm{C}^{\prime}\right), 71.9\left(\mathrm{C}^{\prime}\right), 86.2\left(\mathrm{C}^{\prime}\right), 87.8\left(\mathrm{C}^{\prime}\right), 110.8(\mathrm{C} 5)$, 137.0 (C6), 150.6 (C2), 164.2 (C4). Negative ion ESI-MS: m/z obsd. 355.15 [M-H] ${ }^{-}, 391.13$ [M+Cl] ${ }^{-}$, calcd. $355.1689[\mathrm{M}-\mathrm{H}]^{-}, 391.15[\mathrm{M}+\mathrm{Cl}]^{-}$.

$N^{4}$-Benzoyl-3'-O-(tert-butyldimethylsilyl)-2'-deoxycytidine (2b). Compd. 1b (1.31 mmol, $\left.0.98 \mathrm{~g}\right)$ was dissolved in DCM $(5 \mathrm{~mL})$ containing 3\% dichloroacetic acid $(150 \mu \mathrm{L})$ and $\mathrm{MeOH}(2 \mathrm{~mL})$ was added. After $2 \mathrm{~h}$ stirring at r.t., DCM/aq. $\mathrm{NaHCO}_{3}$ work-up was carried out and the organic phase was dried over $\mathrm{Na}_{2} \mathrm{SO}_{4}$. The solvent was removed by evaporation, and the residue was purified by a silica gel column chromatography (a stepwise gradient of $1-10 \% \mathrm{MeOH}$ in DCM) to obtain $\mathbf{2 b}$ in $90 \%$ yield as white solid foam $(1.17 \mathrm{mmol}, 0.52 \mathrm{~g})$. The ${ }^{1} \mathrm{H}$ - and ${ }^{13} \mathrm{C}-\mathrm{NMR}$ spectra were identical with those reported in literature [19]. Negative ion ESI-MS: $m / z$ obsd. $444.20[\mathrm{M}-\mathrm{H}]^{-}$; calcd. $444.20[\mathrm{M}-\mathrm{H}]^{-}$.

$N^{6}$-Benzoyl-3'-O-(tert-butyldimethylsilyl)-2'-deoxyadenosine (2c) was obtained in 84\% yield (1.32 mmol, $0.62 \mathrm{~g}$ ) from $\mathbf{1 c}$ as described above for $\mathbf{2 b}$. The ${ }^{1} \mathrm{H}-\mathrm{NMR}$ spectrum was identical with that reported in literature [29]. ${ }^{13} \mathrm{C}-\mathrm{NMR}\left(126 \mathrm{MHz}, \mathrm{CD}_{3} \mathrm{CN}\right): \delta=-4.9(\mathrm{SiMe} 2), 17.3\left(\mathrm{Si}-\mathrm{CMe}_{3}\right), 24.8\left(\mathrm{Si}-\mathrm{CMe}_{3}\right), 40.0$ (C2'), 61.6 (C5'), $72.5\left(\mathrm{C}^{\prime}\right), 85.2\left(\mathrm{C}^{\prime}\right), 88.7$ (C1'), 124.3 (C5), 127.8 (Bz), 128.2 (Bz), $132.2(\mathrm{Bz})$, 133.6 (Bz), $142.6(\mathrm{C} 8), 149.6(\mathrm{C} 4), 151.1$ (C2\&C6), $165.0(\mathrm{Bz})$. High resolution negative ion ESI-MS: $\mathrm{m} / \mathrm{z}$ obsd. $468.2067[\mathrm{M}-\mathrm{H}]^{-}$; calcd. $468.2067[\mathrm{M}-\mathrm{H}]^{-}$.

5'-O-(1-Methoxy-1-methylethyl)-3'-O-(tert-butyldimethylsilyl)thymidine (3a). Compound 2a (0.42 mmol, $150 \mathrm{mg}$ ) was dissolved in 1,4-dioxane $(5 \mathrm{~mL})$ and 11 equiv. of 2-methoxypropene (4.47 mmol, $0.400 \mathrm{~mL})$ and 0.02 equiv. of $p$-toluenesulfonic acid monohydrate $(4.2 \mathrm{mmol}, 0.80 \mathrm{~g})$ in dioxane $(4 \mathrm{~mL})$ were added. In $1 \mathrm{~h}$, all the starting material had disappeared. The crude product was purified by silica gel column chromatography using EtOAc containing $1 \%$ petroleum ether and $\mathrm{Et}_{3} \mathrm{~N}$ as an eluent. The yield was $91 \% .{ }^{1} \mathrm{H}-\mathrm{NMR}\left(500 \mathrm{MHz}, \mathrm{CDCl}_{3}\right): \delta=-0.01$ (s, 6H, SiMe $), 0.81$ (s, 9H, $\left.\mathrm{SiCMe}_{3}\right), 1.31(\mathrm{~s}, 6 \mathrm{H}$, $\left.\mathrm{OC}(\mathrm{OMe}) \mathrm{Me}_{2}\right), 1.84$ (s, 3H, C5-Me), 1.95-2.06 (m, 1H, H2'), 2.15-2.25 (m, 1H, H2'), 3.14 (s, 3H, $\left.\mathrm{OC}(\mathrm{OMe}) \mathrm{Me}_{2}\right), 3.47-3.92\left(\mathrm{~m}, 3 \mathrm{H}, \mathrm{H}^{\prime} \& 2 \times \mathrm{H} 5^{\prime}\right), 4.32-4.36\left(\mathrm{~m}, 1 \mathrm{H}, \mathrm{H} 3^{\prime}\right), 6.24-6.26\left(\mathrm{~m}, 1 \mathrm{H}, \mathrm{H} 1^{\prime}\right)$, $7.46(\mathrm{~s}, 1 \mathrm{H}, \mathrm{H} 6), 10.00(\mathrm{~s}, 1 \mathrm{H}, \mathrm{NH}) ;{ }^{13} \mathrm{C} \mathrm{NMR}\left(126 \mathrm{MHz}, \mathrm{CDCl}_{3}\right): \delta=-4.9$ and $-4.8\left(\mathrm{SiMe}_{2}\right)$, 12.4 (C5-Me), 17.9 ( $\left.\mathrm{Si}_{-} \mathrm{CMe}_{3}\right), 24.3$ (C5'-OC(OMe)Me$\left.e_{2}\right), 25.6 \quad\left(\mathrm{Si}_{-}-\mathrm{CMe}_{3}\right), 41.2$ (C2'), 48.6 (C5'-OC(OMe)Me $)_{2}$ ), $60.3\left(\mathrm{C}^{\prime}\right), 72.2$ (C3'), 84.7 (C4'), 86.2 (C1'), 100.2 (C5'-OC(OMe)Me $\left.)_{2}\right), 110.6$ (C5),135.3 (C6), 150.6 (C2), 164.2 (C4). High resolution positive ion ESI-MS: $m / z$ obsd. 451.2241 $[\mathrm{M}+\mathrm{Na}]^{+}$; calcd. $451.2240[\mathrm{M}+\mathrm{Na}]^{+}$.

$N^{4}$-Benzoyl-5'-O-(1-methoxy-1-methylethyl)-3'-O-(tert-butyldimethylsilyl)-2'-deoxycytidine (3b) was obtained in 91\% yield (1.06 mmol, $0.55 \mathrm{~g})$ from compd. 2b, as described above for compd. 3a. ${ }^{1} \mathrm{H}-\mathrm{NMR}\left(400 \mathrm{MHz}, \mathrm{CDCl}_{3}\right): \delta=-0.07$ (s, 6H, SiMe $), 0.82\left(\mathrm{~s}, 9 \mathrm{H}, \mathrm{SiCMe}_{3}\right), 1.33$ and 1.35 (s, $2 \times 3 \mathrm{H}$, 
$\mathrm{OC}(\mathrm{OMe}) \mathrm{Me}_{2}$ ), 2.11-2.17 (m, 1H, H2'), 2.43-2.50 (m, 1H, H2'), 3.17 (s, 3H, OC(OMe) $\left.\mathrm{Me}_{2}\right), 3.53$ (dd, $J=10.9$ and $\left.2.6 \mathrm{~Hz}, 1 \mathrm{H}, \mathrm{H} 5^{\prime}\right), 3.70\left(\mathrm{dd}, J=10.9\right.$ and 3.0, $\left.1 \mathrm{H}, \mathrm{H} 5^{\prime \prime}\right), 3.97-4.01$ (m, 1H, H4'), 4.30-4.34 (m, 1H, H3'), 6.17-6.20 (m, 1H, H1'), 7.44 (t, $J=7.7 \mathrm{~Hz}, 3 \mathrm{H}, \mathrm{Bz} \& \mathrm{H} 5), 7.53$ (t, $J=7.7 \mathrm{~Hz}, 1 \mathrm{H}, \mathrm{Bz})$, 7.85 (d, $J=7.7 \mathrm{~Hz}, 2 \mathrm{H}, \mathrm{Bz}) ; 8.45$ (d, $J=7.5 \mathrm{~Hz}, 1 \mathrm{H}, \mathrm{H} 6), 9.22$ (br s, $1 \mathrm{H}, \mathrm{NH}) ;{ }^{13} \mathrm{C}-\mathrm{NMR}(101 \mathrm{MHz}$, $\left.\mathrm{CDCl}_{3}\right): \delta=-4.9$ and $-4.6\left(\mathrm{SiMe}_{2}\right), 17.9\left(\mathrm{Si}_{-} \mathrm{CMe}_{3}\right), 24.3\left(\mathrm{C} 5^{\prime}-\mathrm{OC}(\mathrm{OMe}) \mathrm{Me}_{2}\right), 25.6\left(\mathrm{Si}-\mathrm{CMe}_{3}\right), 42.1$ (C2'), 48.7 (C5'-OC(OMe)Me $), 59.1$ (C5'), 70.3 (C3'), 86.3 (C4'), 86.9 (C1'), 96.0 (C5), 100.3 (C5'-OC(OMe)Me $), 127.7$ (Bz), 128.8 (Bz), 133.0 (Bz), 133.2 (Bz), 144.7 (C6), 154.7 (C2), 162.3 (C4), $167.0(\mathrm{Bz})$. High resolution negative ion ESI-MS: $\mathrm{m} / z$ obsd. $516.2564[\mathrm{M}-\mathrm{H}]^{-}$; calcd. 516.2530 $[\mathrm{M}-\mathrm{H}]^{-}$.

$N^{6}$-Benzoyl-5'-O-(1-methoxy-1-methylethyl)-3'-O-(tert-butyldimethylsilyl)-2'-deoxyadenosine (3c) was obtained in $81 \%$ yield $(1.07 \mathrm{mmol}, 0.58 \mathrm{~g})$ from compd. 2c, as described above for compd. 3a. ${ }^{1} \mathrm{H}-\mathrm{NMR}\left(500 \mathrm{MHz}, \mathrm{CD}_{3} \mathrm{CN}\right): \delta=0.00(\mathrm{~s}, 6 \mathrm{H}, \mathrm{SiMe}), 0.80\left(\mathrm{~s}, 9 \mathrm{H}, \mathrm{SiCMe}_{3}\right), 1.14(\mathrm{~s}, 6 \mathrm{H}$, $\mathrm{OC}(\mathrm{OMe}) \mathrm{Me}_{2}, 2.27-2.37$ (m, 1H, H2'), 2.67-2.73 (m, 1H, H2'), 2.92 (s, 3H, OC(OMe)Me $), 3.36-4.03$ $\left(\mathrm{m}, 3 \mathrm{H}, \mathrm{H} 4^{\prime} \& 2 \times \mathrm{H}^{\prime}\right), 4.56-4.62\left(\mathrm{~m}, 1 \mathrm{H}, \mathrm{H} 3^{\prime}\right), 6.32\left(\right.$ br s, $\left.1 \mathrm{H}, \mathrm{H} 1^{\prime}\right), 7.37$ (t, $\left.J=7.7 \mathrm{~Hz}, 2 \mathrm{H}, \mathrm{Bz}\right)$, 7.47 (t, $J=7.7 \mathrm{~Hz}, 1 \mathrm{H}, \mathrm{Bz}), 7.86$ (d, $J=7.7 \mathrm{~Hz}, 2 \mathrm{H}, \mathrm{Bz}), 8.24$ (s, 1H, H2), 8.50 (s, 1H, H8), 9.44 $(\mathrm{s}, 1 \mathrm{H}, \mathrm{NH}) ;{ }^{13} \mathrm{C}-\mathrm{NMR}\left(126 \mathrm{MHz}, \mathrm{CD}_{3} \mathrm{CN}\right): \delta=-6.0(\mathrm{SiMe}), 17.3\left(\mathrm{Si}-\mathrm{CMe}_{3}\right), 23.2$ and 23.4 (C5'-OC(OMe) $\left.\mathrm{Me}_{2}\right), 24.8$ ( $\left.\mathrm{Si}-\mathrm{CMe}_{3}\right), 39.7$ (C2'), 47.5 (C5'-OC(OMe)Me 2$), 60.0\left(\mathrm{C5}^{\prime}\right), 72.0\left(\mathrm{C}^{\prime}\right.$ '), 83.9 (C4'), 86.1 (C1'), 99.6 (C5'-OC(OMe)Me $), 124.2$ (C5), 127.8 (Bz), $128.2(\mathrm{Bz}), 132.1$ (Bz), 133.5 (Bz), 141.9 (C8), 149.4 (C4), 151.5 (C2\&C6), 164.9 (Bz). Hugh resolution negative ion ESI-MS: $m / z$ obsd. $540.2663[\mathrm{M}-\mathrm{H}]^{-}$, calcd. $540.2642[\mathrm{M}-\mathrm{H}]^{-}$.

5'-O-(1-Methoxy-1-methylethyl)thymidine (4a). Compound 3a $(0.38 \mathrm{mmol}, 165 \mathrm{mg})$ was treated with 2 equiv. of tetrabutylammonium fluoride $(0.75 \mathrm{mmol}, 0.197 \mathrm{~g})$ in THF $(4 \mathrm{~mL})$. After stirring for $4.5 \mathrm{~h}$ at r.t., the mixture was equilibrated between EtOAc and aq. $\mathrm{NaHCO}_{3}$, the organic phase was evaporated to dryness and the residue was purified by silica gel column chromatography using DCM containing 1-5\% MeOH as eluent. Yield 91\% (111 mg). ${ }^{1} \mathrm{H}-\mathrm{NMR}\left(500 \mathrm{MHz}, \mathrm{CDCl}_{3}\right): \delta=1.39$ and $1.41\left(2 \times \mathrm{s}, 2 \times 3 \mathrm{H}, \mathrm{C}^{\prime}-\mathrm{OC}(\mathrm{OMe}) \mathrm{Me}_{2}\right), 1.93$ (s, 3H, C5-Me), 2.14-2.19 (m, 1H, H2'), 2.38-2.41 (m, 1H, H2'), 3.23 (s, 3H, C5'-OC(OMe)Me $), 3.64$ (d, $\left.J=10.6 \mathrm{~Hz}, 1 \mathrm{H}, \mathrm{H} 5^{\prime}\right), 3.69$ (d, $J=10.6 \mathrm{~Hz}, 1 \mathrm{H}$, H5'), 4.15 (s, 1H, H4'), $4.48\left(\mathrm{~m}, 1 \mathrm{H}, \mathrm{H} 3^{\prime}\right), 6.41\left(\mathrm{dd}, J=6.3\right.$ and $\left.6.3 \mathrm{~Hz}, 1 \mathrm{H}, \mathrm{H} 1^{\prime}\right), 7.61$ (s, 1H, H6), 9.50 (br s, $1 \mathrm{H} \mathrm{NH}) ;{ }^{13} \mathrm{C}-\mathrm{NMR}\left(126 \mathrm{MHz}, \mathrm{CDCl}_{3}\right): \delta=12.3$ (C5-Me), 24.2 (C5'-OC(OMe)Me $), 40.7$ $\left(\mathrm{C} 2^{\prime}\right), 48.6$ (C5'-OC(OMe)Me $), 60.8$ (C5'), 72.2 (C3'), 84.8 (C4'), 85.8 (C1'), 100.2 (C5'$\left.\mathrm{OC}(\mathrm{OMe}) \mathrm{Me}_{2}\right), 110.6$ (C5), 135.6 (C6), 150.4 (C2), 163.8 (C4). High resolution negative ion ESI-MS: $\mathrm{m} / \mathrm{z}$ obsd. $313.1424[\mathrm{M}-\mathrm{H}]^{-}$, calcd. $313.1400[\mathrm{M}-\mathrm{H}]^{-}$.

$N^{4}$-Benzoyl-5'-O-(1-methoxy-1-methylethyl)-2'-deoxycytidine (4b) was obtained in $81 \%$ yield $(0.87 \mathrm{mmol}, 0.35 \mathrm{~g})$ from $\mathbf{3 b}$ as described above for compd. 4a. ${ }^{1} \mathrm{H}-\mathrm{NMR}\left(400 \mathrm{MHz}, \mathrm{CDCl}_{3}\right): \delta=1.28$ and $1.31\left(2 \times \mathrm{s}, 2 \times 3 \mathrm{H}, \mathrm{C} 5^{\prime}-\mathrm{OC}(\mathrm{OMe}) \mathrm{Me}_{2}\right), 2.21-2.28\left(\mathrm{~m}, 1 \mathrm{H}, \mathrm{H} 2^{\prime}\right), 2.65-2.73\left(\mathrm{~m}, 1 \mathrm{H}, \mathrm{H} 2^{\prime}\right), 3.23$ (s, $\left.3 \mathrm{H}, \mathrm{C}^{\prime}-\mathrm{OC}(\mathrm{OMe}) \mathrm{Me}_{2}\right), 3.67\left(\mathrm{dd}, J=10.9\right.$ and $\left.2.9 \mathrm{~Hz}, 1 \mathrm{H}, \mathrm{H} 5^{\prime}\right), 3.76$ (dd, $\left.J=3.0 \mathrm{~Hz}, 1 \mathrm{H}, \mathrm{H} 5^{\prime \prime}\right)$, 4.20-4.24 (m, 1H, H4'), 4.46-4.49 (m, 1H, H3'), 4.30-4.41 (m, 1H, H3'), 6.31-6.34 (m, 1H, H1'), 7.40-7.56 (m, 3H, Bz\&H5), 7.61 (t, $J=7.4 \mathrm{~Hz}, 1 \mathrm{H}, \mathrm{Bz}) 7.93$ (d, $J=7.4 \mathrm{~Hz}, 2 \mathrm{H}, \mathrm{Bz}), 8.48$ (d, $J=7.5 \mathrm{~Hz}$, $1 \mathrm{H}, \mathrm{H} 6) ; 9.60(\mathrm{~s}, 1 \mathrm{H} \mathrm{NH}) ;{ }^{13} \mathrm{C}-\mathrm{NMR}\left(101 \mathrm{MHz}, \mathrm{CDCl}_{3}\right): \delta=24.3\left(\mathrm{C}^{\prime} \mathrm{-OC}(\mathrm{OMe}) \mathrm{Me}_{2}\right), 42.1\left(\mathrm{C} 2^{\prime}\right)$, 
48.8 (C5'-OC(OMe)Me $), 60.1 \quad$ (C5'), 70.6 (C3'), 86.4 (C4'), 87.3 (C1'), 98.2 (C5), 100.3 (C5'-OC(OMe)Me $), 127.7$ (Bz), 128.9 (Bz), 133.1 (Bz), 133.6 (Bz), 145.0 (C6), 155.1 (C2), 162.4 (C4), 167.0 (Bz). High resolution negative ion ESI-MS: $\mathrm{m} / \mathrm{z}$ obsd. $402.1692[\mathrm{M}-\mathrm{H}]^{-}$; calcd. 402.1665 $[\mathrm{M}-\mathrm{H}]^{-}$.

$N^{6}$-Benzoyl-5'-O-(1-methoxy-1-methylethyl)-2'-deoxyadenosine (4c) was obtained in 89\% yield $(0.94 \mathrm{mmol}, 0.40 \mathrm{~g})$ from $3 \mathbf{c}$ as described above for compd. 4a. ${ }^{1} \mathrm{H}-\mathrm{NMR}\left(500 \mathrm{MHz}, \mathrm{CD}_{3} \mathrm{CN}\right)$ : $\delta=1.26\left(2 \mathrm{~s}, 6 \mathrm{H}, \mathrm{C} 5^{\prime}-\mathrm{OC}(\mathrm{OMe}) \mathrm{Me}_{2}\right), 2.40-2.50\left(\mathrm{~m}, 1 \mathrm{H}, \mathrm{H} 2^{\prime}\right), 2.70-2.79\left(\mathrm{~m}, 1 \mathrm{H}, \mathrm{H} 2^{\prime}\right), 3.04$ (s, 3H, C5'-OC(OMe) $\left.\mathrm{Me}_{2}\right), 3.40-4.10$ (m, 3H, H4'\&2 × H5'), 4.56 (m, 1H, H3'), 6.45-6.48 (m, 1H, H1'), 7.50 $(\mathrm{t}, J=7.6 \mathrm{~Hz}, 2 \mathrm{H}, \mathrm{Bz}), 7.60$ (t, $J=7.6 \mathrm{~Hz}, 1 \mathrm{H}, \mathrm{Bz}), 7.99(\mathrm{~d}, J=7.6 \mathrm{~Hz}), 8.42(\mathrm{~s}, 1 \mathrm{H}, \mathrm{H} 2), 8.63(\mathrm{~s}, 1 \mathrm{H}$, $\mathrm{H} 8) ; 9.69$ (s, $1 \mathrm{H}, \mathrm{NH}) ;{ }^{13} \mathrm{C}-\mathrm{NMR}\left(126 \mathrm{MHz}, \mathrm{CD}_{3} \mathrm{CN}\right): \delta=23.3$ and 23.5 (C5'-OC(OMe)Me $)$, $39.6\left(\mathrm{C}^{\prime}\right)$, 47.5 (C5'-OC(OMe)Me 2 ), 60.3 (C5'), 70.8 (C3'), 83.8 (C4'), 85.9 (C1'), 100.3 (C5'-OC(OMe)Me $), 124.0$ (C5), 127.8 (Bz), 128.3 (Bz), 132.2 (Bz), 133.2 (Bz), 141.8 (C8 ), $149.4(\mathrm{C} 4), 151.5$ (C2), 151.6 (C6), $165.1(\mathrm{Bz})$. High resolution negative ion ESI-MS: $m / z$ obsd. $426.1783[\mathrm{M}-\mathrm{H}]^{-}$; calcd. 426.1777 $[\mathrm{M}-\mathrm{H}]^{-}$.

5'-O-(1-Methoxy-1-methylethyl)thymidine 3'-(2-cyanoethyl-N,N-diisopropyl)phosphoramidite (5a). Glassware and stirrer bar were dried for 15 hours in an oven $\left(120^{\circ} \mathrm{C}\right)$. All chemicals and reagents were placed in a box under nitrogen. Compd. 4a (4.27 mmol, $0.40 \mathrm{~g})$ was dissolved in dry DCM (20 mL). Triethylamine (5 equiv., $6.37 \mathrm{mmol}, 0.885 \mathrm{~mL}$ ) and 1-chloro-1-(2-cyanoethoxy)- $N, N$ diisopropylphosphinamine (1.1 equiv., $0.330 \mathrm{~mL})$ were added and the mixture was stirred for $2.5 \mathrm{~h}$ at r.t. under nitrogen. The mixture was then loaded onto a silica gel column and the product was eluted with a 50:49:1 mixture of EtOAc, petroleum ether and $\mathrm{Et}_{3} \mathrm{~N}$. Compd. 5a was obtained as a white foam (yield $85 \%$ ), which was stored at $-18{ }^{\circ} \mathrm{C}$. For the mixture of $R_{\mathrm{P}}$ and $S_{\mathrm{P}}$ diastereomers: ${ }^{1} \mathrm{H}-\mathrm{NMR}$ $\left(500 \mathrm{MHz}, \mathrm{CD}_{3} \mathrm{CN}\right): \delta=1.17(\mathrm{~d}, J=6.8 \mathrm{~Hz}, 12 \mathrm{H}, \mathrm{Pr}), 1.33$ and $1.34\left(2 \times \mathrm{s}, 6 \mathrm{H}, \mathrm{C}^{\prime}-\mathrm{OC}(\mathrm{OMe}) \mathrm{Me}_{2}\right)$, $1.84(\mathrm{~s}, 3 \mathrm{H}, \mathrm{C} 5-\mathrm{Me}), 2.20-2.45\left(\mathrm{~m}, 2 \mathrm{H}, 2 \times \mathrm{H} 2^{\prime}\right), 2.67\left(\mathrm{t}, J=5.9 \mathrm{~Hz}, 2 \mathrm{H}, \mathrm{OCH}_{2} \mathrm{CH}_{2} \mathrm{CN}\right), 3.15$ and $3.17\left(2 \times \mathrm{s}, 3 \mathrm{H}, \mathrm{C}^{\prime}-\mathrm{OC}(\mathrm{OMe}) \mathrm{Me}_{2}\right), 3.53-4.25\left(\mathrm{~m}, 7 \mathrm{H}, 2 \times \mathrm{H}^{\prime} \& \mathrm{H}^{\prime} \& \mathrm{OCH}_{2} \mathrm{CH}_{2} \mathrm{CN} \& 2 \times \mathrm{NCHMe}_{2}\right)$, 4.48-4.59 (m, 1H, H3'), $6.24\left(\mathrm{~m}, 1 \mathrm{H}, \mathrm{H} 1^{\prime}\right), 7.52$ and $7.54(2 \times \mathrm{s}, 1 \mathrm{H}, \mathrm{H} 6), 9.80$ (br s, 1H, NH); ${ }^{13} \mathrm{C}-\mathrm{NMR}\left(126 \mathrm{MHz}, \mathrm{CD}_{3} \mathrm{CN}\right): \delta=11.3(\mathrm{C} 5-\mathrm{Me}), 19.7\left(\mathrm{OCH}_{2} \mathrm{CH}_{2} \mathrm{CN}\right), 23.4\left(\mathrm{C}^{\prime}-\mathrm{OC}(\mathrm{OMe}) \mathrm{Me}_{2}\right)$, $23.6\left(\mathrm{NCHMe}_{2}\right), 38.7\left(\mathrm{C}^{\prime}\right), 42.6\left(\mathrm{C}^{\prime}-\mathrm{OC}(\mathrm{OMe}) \mathrm{Me}_{2}\right), 47.8\left(\mathrm{NCHMe}_{2}\right), 57.9\left(\mathrm{OCH}_{2} \mathrm{CH}_{2} \mathrm{CN}\right), 60.2$ (C5'), 73.4 (C3'), 81.7 (C4'), 84.1 (C1'), 99.8 (C5'-OC(OMe)Me $), 109.9(\mathrm{C} 5), 118.1\left(\mathrm{OCH}_{2} \mathrm{CH}_{2} \mathrm{CN}\right)$, $135.6(\mathrm{C} 6), 150.6(\mathrm{C} 2), 163.8(\mathrm{C} 4) ;{ }^{31} \mathrm{P}-\mathrm{NMR}\left(\mathrm{CD}_{3} \mathrm{CN}\right): \delta=149.3$ and 148.9. Positive ion ESI-MS: $\mathrm{m} / z$ obsd. $537.25[\mathrm{M}+\mathrm{Na}]^{+}$; calcd. $537.25[\mathrm{M}+\mathrm{Na}]^{+}$.

$N^{4}$-Benzoyl-5'-O-(1-methoxy-1-methylethyl)-2'-deoxycytidine $\quad 3$-(2-cyanoethyl- $N, N$-diisopropyl)phosphoramidite (5b) was obtained in $86 \%$ yield $(0.75 \mathrm{mmol}, 0.45 \mathrm{~g})$ from $4 \mathbf{b}$ as described above for compd. 5a. For the mixture of $R_{\mathrm{P}}$ and $S_{\mathrm{P}}$ diastereomers: ${ }^{1} \mathrm{H}-\mathrm{NMR}\left(500 \mathrm{MHz}, \mathrm{CDCl}_{3}\right): \delta=1.20(\mathrm{~d}$, $J=6.6 \mathrm{~Hz}, 12 \mathrm{H}, \mathrm{iPr}), 1.40\left(2 \times \mathrm{s}, 6 \mathrm{H}, \mathrm{C} 5^{\prime}-\mathrm{OC}(\mathrm{OMe}) \mathrm{Me}_{2}\right), 2.20-2.45\left(\mathrm{~m}, 2 \mathrm{H}, 2 \times \mathrm{H} 2^{\prime}\right), 2.64(\mathrm{t}$, $\left.J=5.9 \mathrm{~Hz}, 2 \mathrm{H}, \mathrm{OCH}_{2} \mathrm{CH}_{2} \mathrm{CN}\right), 3.22\left(2 \times \mathrm{s}, 3 \mathrm{H}, \mathrm{C} 5^{\prime}-\mathrm{OC}(\mathrm{OMe}) \mathrm{Me}_{2}\right), 3.45-4.45(\mathrm{~m}, 7 \mathrm{H}$, $\left.2 \times \mathrm{H}^{\prime} \& \mathrm{H}^{\prime} \& \mathrm{OCH}_{2} \mathrm{CH}_{2} \mathrm{CN} \& 2 \times \mathrm{NCHMe}_{2}\right), 4.51-4.60\left(\mathrm{~m}, 1 \mathrm{H}, \mathrm{H} 3^{\prime}\right), 6.25-6.35\left(\mathrm{~m}, 1 \mathrm{H}, \mathrm{H} 1^{\prime}\right), 7.46$ (m, 3H, Bz\&H5), 7.57 (m, 1H, Bz), 7.95 (m, 2H, Bz), 8.42 (m, 1H, H6), 9.60 (br s, 1H, NH); ${ }^{13} \mathrm{C}-\mathrm{NMR}\left(126 \mathrm{MHz}, \mathrm{CDCl}_{3}\right): 18.5\left(\mathrm{OCH}_{2} \mathrm{CH}_{2} \mathrm{CN}\right), 22.4$ (C5'-OC(OMe) $\left.\mathrm{Me}_{2}\right), 22.6\left(\mathrm{NCHMe}_{2}\right), 38.9$ 
$\left(\mathrm{C} 2^{\prime}\right), 41.4\left(\mathrm{C}^{\prime}-\mathrm{OC}(\mathrm{OMe}) \mathrm{Me}_{2}\right), 47.0\left(\mathrm{NCHMe}_{2}\right), 57.0\left(\mathrm{OCH}_{2} \mathrm{CH}_{2} \mathrm{CN}\right), 58.2\left(\mathrm{C}^{\prime}\right), 71.1\left(\mathrm{C}^{\prime}\right), 85.2$ (C4'), $86.0\left(\mathrm{Cl}^{\prime}\right), 95.0(\mathrm{C} 5), 98.5\left(\mathrm{C}^{\prime}-\mathrm{OC}(\mathrm{OMe}) \mathrm{Me}_{2}\right), 116.2\left(\mathrm{OCH}_{2} \mathrm{CH}_{2} \mathrm{CN}\right), 126.2(\mathrm{Bz}), 127.2(\mathrm{Bz})$, $131.3(\mathrm{Bz}), 131.4$ (Bz), 143.3 (C6), 152.8 (C2), 156.6 (C4), 150.8 (C2), 165.5 (Bz); ${ }^{31} \mathrm{P}-\mathrm{NMR}$ $\left(\mathrm{CDCl}_{3}\right): \delta=148.5$ and 149.0. Negative ion ESI-MS: $m / z$ obsd. $602.28[\mathrm{M}-\mathrm{H}]^{-}$; calcd. $602.27[\mathrm{M}-\mathrm{H}]^{-}$.

$N^{6}$-Benzoyl-5'-O-(1-methoxy-1-methylethyl)-2'-deoxyadenosine $\quad 3$-(2-cyanoethyl- $N, N$-diisopropyl)phosphoramidite (5c) was obtained in $83 \%$ yield $(0.70 \mathrm{mmol}, 0.44 \mathrm{~g})$ from $4 \mathbf{c}$ as described above for compd. 5a. For the mixture of $R_{\mathrm{P}}$ and $S_{\mathrm{P}}$ diastereomers: ${ }^{1} \mathrm{H}-\mathrm{NMR}\left(500 \mathrm{MHz}, \mathrm{CDCl}_{3}\right): \delta=1.18(\mathrm{~d}$, $J=6.6 \mathrm{~Hz}, 12 \mathrm{H}, \mathrm{iPr}), 1.39$ and $1.41\left(2 \times \mathrm{s}, 6 \mathrm{H}, \mathrm{C} 5^{\prime}-\mathrm{OC}(\mathrm{OMe}) \mathrm{Me}_{2}\right), 2.20-2.45\left(\mathrm{~m}, 2 \mathrm{H}, 2 \times \mathrm{H} 2^{\prime}\right), 2.66(\mathrm{t}$, $\left.J=5.9 \mathrm{~Hz}, 2 \mathrm{H}, \mathrm{OCH}_{2} \mathrm{CH}_{2} \mathrm{CN}\right), 3.22$ and $3.24\left(2 \times \mathrm{s}, 3 \mathrm{H}, \mathrm{C}^{\prime}-\mathrm{OC}(\mathrm{OMe}) \mathrm{Me}_{2}\right), 3.43-4.25(\mathrm{~m}, 7 \mathrm{H}$, $\left.2 \times \mathrm{H}^{\prime} \& \mathrm{H}^{\prime}{ }^{\prime} \& \mathrm{OCH}_{2} \mathrm{CH}_{2} \mathrm{CN} \& 2 \times \mathrm{NCHMe}_{2}\right), 4.53-4.59\left(\mathrm{~m}, 1 \mathrm{H}, \mathrm{H} 3{ }^{\prime}\right), 6.28\left(\mathrm{~m}, 1 \mathrm{H}, \mathrm{H} 1^{\prime}\right), 7.46(\mathrm{~m}, 2 \mathrm{H}$, Bz), 7.58 (m, 1H, Bz), 7.96 (m, 2H, Bz), 8.28 (s, 1H, H2), 8.46 (s, 1H, H8), 9.30 (br s, 1H, NH); ${ }^{13} \mathrm{C}-\mathrm{NMR}\left(126 \mathrm{MHz}, \mathrm{CDCl}_{3}\right): 18.6\left(\mathrm{OCH}_{2} \mathrm{CH}_{2} \mathrm{CN}\right), 22.5$ (C5'-OC(OMe) $\left.\mathrm{Me}_{2}\right), 22.7\left(\mathrm{NCHMe}_{2}\right), 39.3$ (C2'), 41.4 (C5'-OC(OMe)Me $)$, $47.0\left(\mathrm{NCHMe}_{2}\right), 56.9\left(\mathrm{OCH}_{2} \mathrm{CH}_{2} \mathrm{CN}\right), 58.0\left(\mathrm{C5}^{\prime}\right), 70.9\left(\mathrm{C}^{\prime}\right), 83.9$ (C4'), $85.3\left(\mathrm{Cl}^{\prime}\right), 98.5\left(\mathrm{C5}^{\prime}-\mathrm{OC}(\mathrm{OMe}) \mathrm{Me}_{2}\right), 115.9\left(\mathrm{OCH}_{2} \mathrm{CH}_{2} \mathrm{CN}\right), 122.0(\mathrm{C} 5), 126.1(\mathrm{Bz}), 127.0(\mathrm{Bz})$, $131.1(\mathrm{Bz}), 131.4$ (Bz), 142.8 (C8), 148.2 (C4), 150.2 (C6), 150.8 (C2), 163.8 (Bz); ${ }^{31} \mathrm{P}-\mathrm{NMR}$ $\left(\mathrm{CDCl}_{3}\right): \delta=148.5$ and 148.9. Negative ion ESI-MS: $m / z$ obsd. $626.30[\mathrm{M}-\mathrm{H}]^{-}$, calcd. $626.29[\mathrm{M}-\mathrm{H}]^{-}$.

5'-O-(1-Methoxy-1-methylethyl)-3'-O-(hex-5-ynoyl)thymidine (6). Dicyclohexylcarbodiimide (0.722 mmol, $0.149 \mathrm{~g})$ was dissolved in dry dioxane $(2 \mathrm{~mL})$ and the solution obtained was added dropwise on an ice-bath to 5-hexynoic acid $(1.44 \mathrm{mmol}, 0.162 \mathrm{~g}, 0.160 \mathrm{~mL})$ in dioxane $(1 \mathrm{~mL})$. After stirring for $2 \mathrm{~h}$ at r.t., the precipitated dicyclohexylurea was filtrated off and the volatiles were removed under reduced pressure, giving hex-5-ynoic anhydride as a slightly yellow liquid. Compd. 4a (0.35 mmol, $0.111 \mathrm{~g})$ was dissolved in dry pyridine $(5 \mathrm{~mL})$, hex-5-ynoic anhydride and a catalytic amount of dimethylaminopyridine were added, and the reaction was allowed to proceed $17 \mathrm{~h}$ at $\mathrm{rt}$. The mixture was concentrated under reduced pressure and the residue was purified by silica gel chromatography applying gradient elution with $1-5 \% \mathrm{MeOH}$ in DCM containing 1\% triethylamine. Compound 6 was obtained as white foam in 92\% yield (0.32 mmol, $0.132 \mathrm{~g}) .{ }^{1} \mathrm{H}-\mathrm{NMR}\left(500 \mathrm{MHz}, \mathrm{CDCl}_{3}\right): \delta=1.41$ and $1.42(2 \times \mathrm{s}, 2 \times 3 \mathrm{H}, \mathrm{C} 5$ '-OC(OMe)Me $), 1.84-1.89$ (m, 2H, H3 of hex-5-ynoyl), 1.95 (s, 3H, C5-Me), 2.02-2.04 (m, 1H, H2'), 2.18-2.24 (m, 1H, H2'), 2.28-2.31 (m, 2H, H2 of hex-5-ynoyl), 2.39-2.43 (m, 2H, H4 of hex-5-ynoyl), 2.52 (t, $J=7.4 \mathrm{~Hz}, 1 \mathrm{H}, \mathrm{H} 6$ of hex-5-ynoyl), 3.25 (s, 3H, C5'-OC(OMe)Me $\mathrm{M}_{2}$ ), 3.70-3.99 (m, 2H, H5'), 4.21 (m, 1H, H4'), 5.30-5.32 (m, 1H, H3'), 6.43 (dd, J=6.3 Hz, 1H, H1'), 7.62 (s, 1H, H6), 9.50 (s, 1H NH); ${ }^{13} \mathrm{C}-\mathrm{NMR}\left(126 \mathrm{MHz}, \mathrm{CDCl}_{3}\right): \delta=12.5(\mathrm{C} 5-\mathrm{Me}), 17.7$ (C4 of hex-5ynoyl), 23.3 (C3 of hex-5-ynoyl), 24.4 (C5'-OC(OMe)Me 2 ), 32.7 (C2 of hex-5-ynoyl), 37.9 (C2'), 48.8 (C5'-OC(OMe)Me $), 61.1$ (C5'), 69.5 (C6 of hex-5-ynoyl), 75.4 (C3'), 82.9 (C5 of hex-5-ynoyl), 83.9 (C4'), 84.6 (C1'), 100.4 (C5'-OC(OMe)Me $), 111.2$ (C5), 135.2 (C6), 150.8 (C2), 164.0 (C4), 172.7 $\left(\mathrm{C}=\mathrm{O}\right.$ of hex-5-ynoyl). High resolution negative ion ESI-MS: $m / z$ obsd. $407.1841[\mathrm{M}-\mathrm{H}]^{-}$, calcd. $407.1818[\mathrm{M}-\mathrm{H}]^{-}$.

5'-O-(4,4'-Dimethoxytrityl)-3'-O-(hex-5-ynoyl)thymidine (7). Thymidine was converted to 5'-O-(4,4'dimethoxytrityl)thymidine as described in literature [30] and acylated with hex-5-ynoic anhydride as described above for compound 6 . The yield of acylation was $99 \% .{ }^{1} \mathrm{H}-$ and ${ }^{13} \mathrm{C}-\mathrm{NMR}$ spectroscopic 
data was identical with that given by Oyelere et al. [31]. High resolution negative ion ESI-MS: $m / z$ obsd. $637.2534[\mathrm{M}-\mathrm{H}]^{-}$, calcd. $637.2550[\mathrm{M}-\mathrm{H}]^{-}$.

6-O-(p-Toluenesulfonyl)- $\beta$-cyclodextrin (8). Monotosylated $\beta$-cyclodextrin was prepared by the method of Kuzuya et al. [19] The ${ }^{1} \mathrm{H}$ - and ${ }^{13} \mathrm{C}-\mathrm{NMR}$ spectra of the product were identical to those reported previously in literature [32]. Negative ion ESI-MS: $m / z$ obsd $1287.41[\mathrm{M}-\mathrm{H}]^{-}$, calcd. 1287.37 $[\mathrm{M}-\mathrm{H}]^{-}$.

6-Azido-6-deoxy- $\beta$-cyclodextrin (9) was obtained by displacing the $p$-toluenesulfonyloxy group from compd. 8 with azide ion as reported by Petter et al. [32]. The ${ }^{1} \mathrm{H}$ - and ${ }^{13} \mathrm{C}-\mathrm{NMR}$ chemical shifts were identical with those reported previously [32]. Negative ion ESI-MS: $m / z$ obsd. 1158.36 [M-H] ${ }^{-}$, calcd. $1158.37[\mathrm{M}-\mathrm{H}]^{-}$.

Peracetylated 6-azido-6-deoxy- $\beta$-cyclodextrin (10a). The azido-functionalized $\beta$-cyclodextrin (9) was peracetylated with acetic anhydride in pyridine at r.t., using 4 quiv. of acetic anhydride compared to the amount of free $\mathrm{OH}$ groups. The product was purified by silica gel chromatography applying a stepwise gradient elution with $1-5 \% \mathrm{MeOH}$ in DCM containing 1\% $\mathrm{Et}_{3} \mathrm{~N}$. The yield was $73 \%$. ${ }^{1} \mathrm{H}-\mathrm{NMR}\left(500 \mathrm{MHz}, \mathrm{DMSO}-d_{6}\right) 2.05$ (br s, 60H, Ac), 3.65 (d, $\left.J=10 \mathrm{~Hz}, 1 \mathrm{H}, \mathrm{CHHN}_{3}\right), 3.77$ (d, $J=10 \mathrm{~Hz}$, $\mathrm{CH} H \mathrm{~N}_{3}$ ), 3.85-3.90 (br s, 7H, H4), 4.03-4.12 (m, 7H, H5), 4,18-4.28 (m, 6H, H6b), 4.40-4.50 (m, 6H, H6a), 4.65-4.75 (m, 7H, H2), 5.00-5.15 (m, 7H, H3), 5.18-5.23 (m, 7H, H1); ${ }^{13} \mathrm{C}-\mathrm{NMR}(126 \mathrm{MHz}$, DMSO- $d_{6}$ ): 169.5 (Ac), 97.2 (C1), 77.3 (C4), 71.0 (C5), 70.8 (C3), 70.0 (C2), 62.6 (C6), 50.8 $\left(\mathrm{CH}_{2} \mathrm{~N}_{3}\right), 21.0$ (Ac). Positive ion ESI-MS: $m / z$ obsd. $2022.56[\mathrm{M}+\mathrm{Na}]^{+}$, calcd. $2022.58[\mathrm{M}+\mathrm{Na}]^{+}$.

Permethylated 6-azido-6-deoxy- $\beta$-cyclodextrin (10b). Permethylation of the azido-functionalized $\beta$-cyclodextrin was achieved by treating 9 over a weekend with a modest excess of methyl iodide (1.25 equiv.) and sodium hydroxide (1.25 equiv.) compared to the amount of free hydroxyl functions, as described previously by Schomburg et al. [20,21]. The yield was 91\%. The ${ }^{1} \mathrm{H}-\mathrm{NMR}$ spectrum was identical with that reported earlier [33]. ${ }^{13} \mathrm{C}-\mathrm{NMR}\left(126 \mathrm{MHz}, \mathrm{DMSO}-d_{6}\right)$ : 96.8 (C1), 80.6 (C3), 80.2 (C2), $78.4(\mathrm{C} 4), 70.2\left(C 5-\mathrm{CH}_{2} \mathrm{~N}_{3}\right), 69.4\left(\mathrm{C} 6-\mathrm{N}_{3}\right), 59.8(\mathrm{O} 6-\mathrm{Me}), 57.0(\mathrm{O} 2-\mathrm{Me} \& \mathrm{O} 3-\mathrm{Me}), 50.4\left(\mathrm{CH}_{2} \mathrm{~N}_{3}\right)$. Negative ion ESI-MS: $m / z$ obsd. $1474.76[\mathrm{M}+\mathrm{Cl}]^{-}$, calcd. $1475.66[\mathrm{M}+\mathrm{Cl}]^{-}$.

Immobilization of 3'-O-(hex-5-ynoyl)thymidines to cyclodextrin supports. 3'-O-(hex-5-ynoyl)thymidines $\mathbf{6}$ and 7 were immobilized to the azido-functionalized supports 10a,b by $\mathrm{Cu}^{+}$-promoted 1,3-dipolar cyclo addition. Accordingly, the appropriate nucleoside, either $6(3.03 \mathrm{mmol}, 1.25 \mathrm{~g})$ or 7 (1.03 mmol, $0.66 \mathrm{~g})$ in dioxane $(15 \mathrm{~mL})$ was mixed with either $\mathbf{1 0 a}$ or $\mathbf{1 0 b}$ in the same solvent. Aq. $\mathrm{CuSO}_{4}\left(50 \mathrm{mmol} \cdot \mathrm{L}^{-1}\right)$ and sodium ascorbate $\left(0.1 \mathrm{mmol} \cdot \mathrm{L}^{-1}\right)$ were added and the reaction was allowed to proceed for $3 \mathrm{~d}$ at r.t. Aq. $\mathrm{CuSO}_{4} \cdot 5 \mathrm{H}_{2} \mathrm{O}$ and aq. sodium ascorbate were added daily to ensure quantitative formation of the 1,2,3-triazole linkages. The products 11 a-c were obtained in about $50 \%$ yield as white foams by silica gel chromatography applying first a stepwise gradient from $4 \%$ to $34 \%$ cyclohexane in EtOAc containing $1 \%$ triethylamine, and then a stepwise gradient of $5 \%$ to $10 \% \mathrm{MeOH}$ in $\mathrm{DCM}$ containing $1 \%$ triethylamine. The identity and homogeneity of the products were verified by ESI-MS and HPLC, respectively. 


\subsection{Oligonucleotide Synthesis}

\subsubsection{Chain Assembly from 5'-O-(4,4'-Dimethoxytrityl) Protected Nucleoside Phosphoramidites}

Support 11b $(0.180 \mathrm{~g}, 68.2 \mu \mathrm{mol})$ was dissolved in DCM containing 3\% dichloroacetic acid $(5 \mathrm{~mL})$ and stirred for $1 \mathrm{~h}$. The mixture was diluted with DCM $(25 \mathrm{~mL})$ and washed with saturated aq. sodium bicarbonate $(3 \times 10 \mathrm{~mL})$. Combined aqueous phases were back-extracted with DCM $(20 \mathrm{~mL})$. The combined organic phases were dried over anhydrous sodium sulfate and evaporated to dryness, giving $0.177 \mathrm{~g}$ deprotected material that still contained the DMTr alcohol. The product was subjected to coupling without purification.

Deprotected 11b (0.177 g) and commercially available 5'-O-DMTr-thymidine 3'-(2-cyanoethyl$N, N$-diisopropylphosphoramidite ( 1.5 equiv., $100.6 \mu \mathrm{mol}, 0.075 \mathrm{~g}$ ) were dissolved in anhydrous $\mathrm{MeCN}$ $(0.775 \mathrm{~mL})$ under nitrogen and $0.45 \mathrm{~mol} \cdot \mathrm{L}^{-1}$ solution of tetrazole in $\mathrm{MeCN}$ (1.5 equiv., $0.225 \mathrm{~mL}$ ) was added. The mixture was stirred under nitrogen for $1 \mathrm{~h}$, iodine oxidation solution $\left(\mathrm{I}_{2}: \mathrm{H}_{2} \mathrm{O}: \mathrm{THF}: 2,6-\right.$ lutidine $0.43 \mathrm{~g}: 4 \mathrm{~mL}: 8 \mathrm{~mL}: 2 \mathrm{~mL} ; 1.2$ equiv., $0.820 \mathrm{~mL}$ ) was added and stirred for additional $30 \mathrm{~min}$. The mixture was concentrated under reduced pressure, the residue was dissolved in DCM (20 mL) and washed with saturated aq sodium bisulfite $(3 \times 10 \mathrm{~mL})$ and brine $(3 \times 10 \mathrm{~mL})$. Combined aqueous phases were back-extracted with DCM $(20 \mathrm{~mL})$. The organic phases were combined, dried over anhydrous sodium sulfate and evaporated to dryness to give $0.196 \mathrm{~g}$ of white foam. The product was used for the next coupling cycle without purification. According to UV-spectrophotometric assay, the trimer was obtained in $85 \%$ yield, which corresponds to $92 \%$ coupling yield. The homogeneity of product was verified by RP-HPLC (see Figure 2A).

\subsubsection{Chain Assembly from 5'-O-(1-Methoxy-1-methylethyl) Protected Nucleoside Phosphoramidites}

Glassware and stirrer bar were dried in the oven $\left(120^{\circ} \mathrm{C}\right)$. All chemicals and reagents were placed in a box under Nitrogen atmosphere. The solvents were dried over $3 \AA$ molecular sieves.

Acetylated and methylated cyclodextrin supports 11a and 11c were treated with a mixture of $\mathrm{MeOH}$ $(2 \mathrm{~mL})$ and $0.1 \mathrm{~mol} \cdot \mathrm{L}^{-1} \mathrm{HCl}$ in 1,4-dioxane $(6 \mathrm{~mL})$ for $30 \mathrm{~min}$ at r.t. The volatiles were removed under reduced pressure and traces of $\mathrm{MeOH}$ were removed by coevaporation with dry pyridine and $\mathrm{MeCN}$. Support 11c was additionally purified chromatographically to remove the 4,4'-dimethoxytrityl alcohol released. Deprotected support 11a was used to assemble $3^{\prime}-\mathrm{TTT}-5^{\prime}$ and support 11c to assemble 3'-TTT-5' and 3'-TTCAT-5'.

The deprotected support was dissolved in $\mathrm{MeCN}(2 \mathrm{~mL})$ and the desired 5'-acetal protected building block (5a-c) in $\mathrm{MeCN}$ (1.5 equiv. in $1 \mathrm{~mL}$ ) and 4,5-dicyanoimidazole (1.5 equiv. in $0.52 \mathrm{~mL} \mathrm{MeCN}$ ) were added under nitrogen. The mixture was stirred for $6 \mathrm{~h}$ and the oxidation solution $(1.1 \mathrm{~mL}$ containing 1.5 equiv. of iodine in a 2:4:1 mixture of water, THF and 2,6-lutidine) was added. After 30 min stirring, the mixture was diluted with DCM $(20 \mathrm{~mL})$ and washed with an equal volume of aq. $\mathrm{NaHSO}_{3}$ to remove the traces of iodine. The organic phase was dried over $\mathrm{Na}_{2} \mathrm{SO}_{4}$, filtered and evaporated to dryness under reduced pressure. The residue that still contained traces of 2,6-lutidine, was dissolved in $\mathrm{MeOH}(2 \mathrm{~mL})$ and a sufficient volume of $0.1 \mathrm{~mol} \mathrm{~L}^{-1} \mathrm{HCl}$ in dioxane was added to neutralize lutidine and adjust $\mathrm{pH}$ slightly below 4 . After $30 \mathrm{~min}$ at r.t., the mixture was evaporated to dryness and the residue was coevaporated with pyridine and $\mathrm{MeCN}$, and subjected to flash 
chromatographic separation with $1-15 \% \mathrm{MeOH}$ in DCM to remove the remnants of the first coupling reaction. The subsequent couplings were then carried out in a similar manner, except that upon the two last couplings the support was dissolved in a 4:1 $(v / v)$ mixture of MeCN and DCM instead of MeCN. The identitiy of the product was checked by negative ion ESI-MS after each coupling and deprotection.

On assembling the $3^{\prime}$-TTT-5' trimer on the acetylated support 11a, the negative ion ESI-MS values after each coupling and deprotection were (calculated values in parentheses): CD-T 2334.7 (2334.7) $[\mathrm{M}-\mathrm{H}]^{-}$, CD-TT 2691.7 (2691.8) [M-H] $]^{-}$, CD-TTT 3048.8 (3048.9) [M-H] . The spectrophotometrically determined yield was $87 \%$, corresponding to $93 \%$ average coupling yield. On assembling the same trimer on the methylated support 11c, the negative ion ESI -MS $\mathrm{m} / \mathrm{z}$ values for the support-bound phosphate protected trimer were 2489.0 (calcd. 2489.0). In both cases, the $m / z$ value for the released and deprotected $3^{\prime}-$ TTT-5' was 849.15 (calcd. 849.17). The homogeneity of the products was verified by RP-HPLC (see Figure 2 B and C).

On preparing the pentamer on methylated cyclodextrin support 11c (96 $\mu \mathrm{mol}, 170 \mathrm{mg})$, the identity of the product was checked by negative ion ESI-MS after each coupling and deprotection (calculated values in parentheses): CD-T 1774.8 (1774.8) [M-H] ${ }^{-}$, CD-TT 2131.8 (2131.9) [M-H] $]^{-}$, CD-TTC 2578.1 (2578.0) $[\mathrm{M}-\mathrm{H}]^{-}$, CD-TTCA 1523.6 (1523.5) $[\mathrm{M}-2 \mathrm{H}]^{2-}$, CD-TTCAT 1702.0 (1702.1) $[\mathrm{M}-2 \mathrm{H}]^{2-}$. The overall yields after each coupling and subsequent removal of the $5^{\prime}$-protecting group were (CD refers to the cyclodextrin support): CD-TT-5' (88\%, $84 \mu \mathrm{mol}, 180 \mathrm{mg}$ ), CD-TTC-5' (77\%, $74 \mu \mathrm{mol}, 190 \mathrm{mg})$, CD-TTCA-5' (64\%, $61 \mu \mathrm{mol}, 186 \mathrm{mg})$ and CD-TTCAT-5' (52\%, $50 \mu \mathrm{mol}, 170 \mathrm{mg})$. The identity of the released and deprotected pentamer was verified by negative ion ESI ${ }^{-}$-MS: $m / z$ obsd. 1451.31 [M-H] $]^{-}$, calcd. $1451.28[\mathrm{M}-\mathrm{H}]^{-}$. The homogeneity of the product was verified by reversed phase HPLC (see Figure 4). The mass of the crude product (after removal of the support by extraction) was $64 \mathrm{mg}$ and the isolated yield (after HPLC purification) $52 \mathrm{mg}$ (37\% of theoretical).

\section{Conclusions}

A useful method for the preparation of short oligodeoxyribonucleotides in solution has been developed. The essential features of the method include use of 1-methoxy-1-methylethyl group as the 5 '-O protecting group and permethylated $\beta$-cyclodextrin as a soluble support. Acid-catalyzed methanolysis of this $5^{\prime}$-acetal protection gives easily removable volatile products and hydrophobic cyclodextrin support allows efficient coupling on using only $50 \%$ excess of the monomeric building block, rapid flash chromatographic purification after each coupling cycle and extractive removal of the support after ammonolytic release/deprotection of the oligonucleotide.

\section{Acknowledgments}

Financial support from the FP7 Marie Curie Actions is gratefully acknowledged.

\section{References}

1. Beaucage, S.L.; Iyer, R.P. Advances in the synthesis of oligonucleotides by the phosphoramidite approach. Tetrahedron 1992, 48, 2223-2311. 
2. Hayakawa, Y. Toward an ideal synthesis of oligonucleotides: Development of a novel phosphoramidite method with high capability. Bull. Chem. Soc. Jpn. 2001, 74, 1547-1565.

3. Cheruvalleth, S.Z.; Carty, R.L.; Moore, M.H.; Capaldi, D.C.; Krotz, A.H.; Wheeler, P.D.; Turney, B.J.; Craig, S.R.; Gaus, H.J.; Scozzari, A.N.; et al. Synthesis of antisense oligonucleotides: Replacement of 3H-1,2-benzodithiol-3-one 1,1-dioxide (Beaucage reagent) with phenylacetyl disulfide (PADS) as efficient sulfurization reagent: From bench to bulk manufacture of active pharmaceutical ingredient. Org. Process Res. Dev. 2000, 4, 199-204.

4. Pon, R.T.; Yu, S.; Guo, Z.; Deshmukh, R.; Sanghvi, Y.S. Reusable solid-phase supports for oligonucleotides and antisense therapeutics. J. Chem. Soc. Perkin Trans. 1 2001, 2638-2643.

5. Sanghvi, Y.S.; Schulte, M. Therapeutic oligonucleotides: The state-of-the-art in purification technologies. Curr. Opin. Drug Discov. Dev. 2004, 6, 765-776.

6. Anderson, N.G.; Anderson, N.L.; Taylor, J.; Goodman, J. Large-scale oligonucleotide synthesizers. I. Basic principles and system design. Appl. Biochem. Biotechnol. 1995, 54, 19-42.

7. Bonora, G.M.; Biancotto, G.; Maffini, M.; Scremin, C.L. Large scale, liquid phase synthesis of oligonucleotides by the phosphoramidite approach. Nucleic Acids Res. 1993, 21, 1213-1217.

8. Scremin, C.L.; Bonora, G.M. Liquid phase synthesis of phosphorothioate oligonucleotides on polyethylene glycol support. Tetrahedron Lett. 1993, 29, 4663-4666.

9. Bonora, G.M. Polyethylene-glycol—A high-efficiency liquid-phase (HELP) for the large-scale synthesis of oligonucleotides. Appl. Biochem. Biotechnol. 1995, 54, 3-17.

10. Bonora, G.M.; Rossin, R.; Zaramella, S.; Cole, D.L.; Eleuteri, A.; Ravikumar, V.T. A liquid-phase process suitable for large-scale synthesis of phosphorothioate oligonucleotides. Org. Process Res. Dev. 2000, 4, 225-231.

11. Ballico, M.; Drioli, S.; Morvan, F.; Xodo, L.; Bonora, G.M. Triple, MPEG-conjugated, helix-forming oligonucleotides (TRIPEGXs): Liquid-phase synthesis of natural and chimeric "All-purine" sequences linked to high molecular weight poly(ethylene glycols). Bioconjug. Chem. 2001, 12, 719-725.

12. Padiya, K.J.; Salunkhe, M.M. Large Scale, Liquid phase oligonucleotide synthesis by alkyl H-phosphonate approach. Bioorg. Med. Chem. 2000, 8, 337-342.

13. Bonora, G.M.; Scremin, C.L.; Colonna, F.P.; Garbesi, A. HELP (high efficiency liquid phase) new oligonucleotide synthesis on soluble polymeric support. Nucleic Acids Res. 1990, 18, 3155-3159.

14. Colonna, F.P.; Scremin, C.L.; Bonora, G.M. Large scale H.E.L.P. synthesis of oligodeoxynucleotides by the hydroxybenzotriazole phosphotriester approach. Tetrahedron Lett. 1991, 32, 3251-3254.

15. De Koning, M.C.; Ghisaidoobe, A.B.T.; Duynstee, H.I.; Kortenaar, P.B.W.T.; Filippov, D.V.; van der Marel, G.A. Simple and efficient solution-phase synthesis of oligonucleotides using extractive work-up. Org. Process Res. Dev. 2006, 10, 1238-1245.

16. Donga, R.A.; Khaliq-Uz-Zaman, S.M.; Chan, T.-H.; Damha, M.J. A novel approach to oligonucleotide synthesis using an imidazolium ion tag as a soluble support. J. Org. Chem. 2006, $71,7907-7910$. 
17. Dueymes, C.; Schönberger, A.; Adamo, I.; Navarro, A.E.; Meyer, A.; Lange, M.; Imbach, J.L.; Link, F.; Morvan, F.; Vasseur, J.J. High-yield solution-phase synthesis of di- and trinucleotide blocks assisted by polymer-supported reagents. Org. Lett. 2005, 7, 3485-3488.

18. Adamo, I.; Dueymes, C.; Schönberger, A.; Navarro, A.E.; Meyer, A.; Lange, M.; Imbach, J.L.; Link, F.; Morvan, F.; Vasseur, J.J. Solution-phase synthesis of phosphorothioate oligonucleotides using a aolid-supported acyl chloride with $H$-Phosphonate Chemistry. Eur. J. Org. Chem. 2006, 436-448.

19. Kuzuya, A.; Ohnishi, T.; Wasano, T.; Nagaoka, S.; Sumaoka, J.; Ihara, T.; Jyo, A.; Komiyama, M. Efficient guest inclusion by $\beta$-cyclodextrin attached to the ends of DNA oligomers upon hybridization to various DNA conjugates. Bioconjug. Chem. 2009, 20, 1643-1649.

20. Schomburg, G.; Deege, A.; Hinrichs, H.; Hubinger, E.; Husmann, H. Preparation, purification, and analysis of alkylated cyclodextrins. J. High Resol. Chromatogr. 1992, 15, 579-584.

21. Schurig, V.; Jung, M.; Schrnalzing, D.; Schleirner, M.; Duvekot, J.; Buyten, J.C.; Peene, J.E.; Mussche, P. CGC enantiomer separation on diluted cyclodextrin derivatives coated on fused silica columns. J. High Resol. Chromatogr. 1990, 13, 470-474.

22. Rostovtsev, V.V.; Green, L.G.; Fokin, V.V.; Sharpless, K.B. A stepwise Huisgen cycloaddition process: Copper(I)-catalyzed regioselective "ligation" of azides and terminal alkynes. Angew. Chem. Int. Ed. Engl. 2002, 41, 2596-2599.

23. Tornoe, C.W.; Christensen, C.; Meldal, M. Peptidotriazoles on solid phase: [1,2,3]-Triazoles by regiospecific copper(I)-catalyzed 1,3-dipolar cycloadditions of terminal alkynes to azides. J. Org. Chem. 2002, 67, 3057-3064.

24. Ogilvie, K.K. The tert-butyldimethylsilyl group as a protecting group in deoxynucleosides. Can. J. Chem. 1973, 51, 3799-3807.

25. Cabral, N.L.D.; Hoeltgebaum Thiessen, L.J.; Doboszwski, B. Protecting group transfer: Unusual method of removal of $\mathrm{Tr}$ and TBDMS groups by transetherification. Nucleos. Nucleot. Nucleic Acids 2008, 27, 931-948.

26. Khan, A.T.; Ghosh, S.; Choudhury, L.H. A simple and useful synthetic protocol for selective deprotection of tert-butyldimethylsilyl (TBS) ethers. Eur. J. Org. Chem. 2004, 2198-2204.

27. De Napoli, L.; Di Fabio, G.; Messere, A.; Montesarchio, D.; Piccialli, G.; Varra, M. A facile solid-phase synthesis of oligonucleotides containing a 3'-3' phosphodiester bond for alternate strand triple-helix formation. Eur. J. Org. Chem. 1998, 2119-2125.

28. Nomura, M.; Shuto, S.; Tanaka, M.; Sasaki, T.; Mori, S.; Shigeta, S.; Matsuda, A. Nucleosides and Nucleotides 185 . Synthesis and biological activities of $4^{\prime} \alpha-C$-branched chain sugar pyrimidine nucleosides. J. Med. Chem. 1999, 42, 2901-2908.

29. Kohgo, S.; Yamada, K.; Kitano, K.; Iwai, Y.; Sakata, S.; Ashida, N.; Hayakawa, H.; Nameki, D.; Kodama, E.; Matsuoka, M.; et al. Design, efficient synthesis and anti-HIV activity of 4'-C-cyanoand 4'-C-ethynyl-2'-deoxy purine nucleosides. Nucleos. Nucleot. Nucleic Acids 2004, 23, 671-690.

30. Lan, T.; McLaughlin, L.W. Minor groove hydration is critical to the stability of DNA duplexes. J. Am. Chem. Soc. 2000, 122, 6512-6513.

31. Oyelere, A.K.; Chen, P.C.; Yao, L.P.; Boguslavsky, N. Heterogeneous diazo-transfer reaction: A facile unmasking of azide groups on amine-functionalized insoluble supports for solid phase synthesis, J. Org. Chem. 2006, 71, 9791-9796. 
32. Petter, R.C.; Salek, J.S.; Sikorski, C.T.; Kumaravel, G.; Lin, F.T. Cooperative binding by aggregated mono-6-(alkylamino)- $\beta$-cyclodextrins. J. Am. Chem. Soc. 1990, 112, 3860-3868.

33. Zhang, J.; Xiao, P.; Shi, S.; Nie, J. Preparation and characterization of a water soluble methylated $\beta$-cyclodextrin/camphorquinone complex. Polym. Adv. Technol. 2009, 20, 723-728.

Sample Availability: Samples of the compounds 1-11 are available from the authors.

(C) 2012 by the authors; licensee MDPI, Basel, Switzerland. This article is an open access article distributed under the terms and conditions of the Creative Commons Attribution license (http://creativecommons.org/licenses/by/3.0/). 